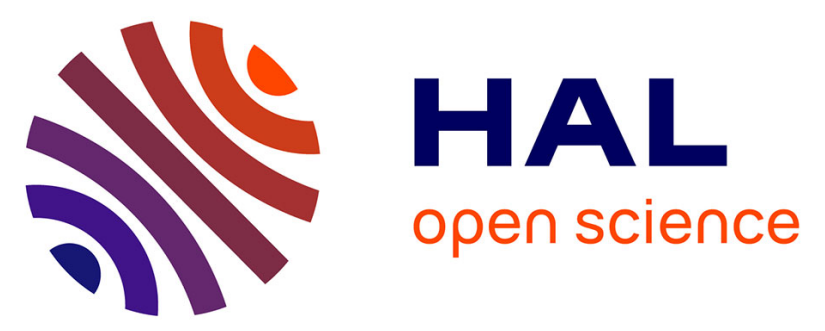

\title{
Description of a new species and new records of Gerromorpha (Insecta: Hemiptera: Heteroptera) from Panama and Colombia
}

Juliana Mourão dos Santos Rodrigues, Antonin Jean Johan Crumiere, Silvia Patricia Mondragón-F, Irina Morales, Abderrahman Khila, Felipe Ferraz

Figueiredo Moreira

\section{To cite this version:}

Juliana Mourão dos Santos Rodrigues, Antonin Jean Johan Crumiere, Silvia Patricia Mondragón-F, Irina Morales, Abderrahman Khila, et al.. Description of a new species and new records of Gerromorpha (Insecta: Hemiptera: Heteroptera) from Panama and Colombia. Zootaxa, 2021, 4958 (1), pp.226-251. 10.11646/zootaxa.4958.1.12 . hal-03079068

\section{HAL Id: hal-03079068 https://hal.science/hal-03079068}

Submitted on 24 Nov 2021

HAL is a multi-disciplinary open access archive for the deposit and dissemination of scientific research documents, whether they are published or not. The documents may come from teaching and research institutions in France or abroad, or from public or private research centers.
L'archive ouverte pluridisciplinaire HAL, est destinée au dépôt et à la diffusion de documents scientifiques de niveau recherche, publiés ou non, émanant des établissements d'enseignement et de recherche français ou étrangers, des laboratoires publics ou privés. 


\title{
Description of a new species and new records of Gerromorpha (Insecta: Hemiptera: Heteroptera) from Panama and Colombia
}

\author{
JULIANA MOURÃO DOS SANTOS RODRIGUES ${ }^{1 *}$, ANTONIN JEAN JOHAN CRUMIÈRE ${ }^{2,4}$, \\ SILVIA PATRICIA MONDRAGÓN-F.,3, IRINA MORALES ${ }^{3,6}$, \\ ABDERRAHMAN KHILA ${ }^{4}$ \& FELIPE FERRAZ FIGUEIREDO MOREIRA ${ }^{1,7}$ \\ ${ }^{1}$ Fundação Oswaldo Cruz, Instituto Oswaldo Cruz, Laboratório de Biodiversidade Entomológica, Avenida Brasil 4365, Rio de Janeiro, \\ RJ, Brazil. \\ ${ }^{2}$ Current address: Section for Ecology and Evolution, Department of Biology, University of Copenhagen, Universitetsparken 15, 2100 \\ Copenhagen, Denmark. झ antonin.crumiere@gmail.com; ๑ https://orcid.org/0000-0003-2214-2993 \\ ${ }^{3}$ Grupo de Investigación Sistemática Biológica, Laboratorio de Entomología, Museo de Historia Natural "Luis Gonzalo Andrade”, \\ Universidad Pedagógica y Tecnológica de Colombia. \\ ${ }^{4}$ Université Claude Bernard Lyon1, Ecole Normale Supérieure de Lyon, Institut de Génomique Fonctionnelle de Lyon, CNRS UMR \\ 5242, 46 allée d'Italie, F-69364, Lyon, France. \\ ”"abderrahman.khila@ens-lyon.fr; 『 https://orcid.org/0000-0003-0908-483X \\ ${ }^{5}$ "=" patriciamondragon18@gmail.com; ه https://orcid.org/0000-0001-6730-1535

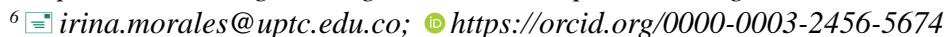 \\ 7 ”- ppmeiameiameia@gmail.com; $\odot$ https://orcid.org/0000-0002-6692-0323 \\ *Corresponding author. ”"julianamourao@yahoo.com.br; @ https://orcid.org/0000-0003-2872-138X
}

\begin{abstract}
The fauna of semiaquatic bugs (Insecta: Hemiptera: Heteroptera: Gerromorpha) from Panama has been explored mainly between the end of the $19^{\text {th }}$ century and the first half of the $20^{\text {th }}$ century, with few reports since then, whereas that from Colombia has been intensively studied in the last decade. Here, we describe Rhagovelia joceliae Rodrigues \& Moreira, sp. nov. (Veliidae: Rhagoveliinae), from Panama. Additionally, new records from these countries are presented for Mesovelia mulsanti White, 1879, Mes. zeteki Harris \& Drake, 1941 (Mesoveliidae: Mesoveliinae), Lipogomphus leucostictus (Champion, 1898) (Hebridae: Hebrinae), Hydrometra caraiba Guérin-Méneville, 1857 (Hydrometridae: Hydrometrinae), Platyvelia brachialis (Stål, 1860), Stridulivelia (Stridulivelia) raspa (Hungerford, 1929) (Veliidae: Veliinae), R. elegans Uhler, 1894, R. perija Polhemus, 1997, R. rosensis Padilla-Gil, 2011 (Veliidae: Rhagoveliinae), Euvelia advena Drake, 1957, Microvelia albonotata Champion, 1898, Mi. fantastika Padilla-Gil, 2019, Mi. mimula White, 1879 (Veliidae: Microveliinae), Metrobates laudatus Drake \& Harris, 1937, Telmatometra ujhelyii Esaki, 1926 (Gerridae: Trepobatinae), Brachymetra albinervus (Amyot \& Serville, 1843) (Gerridae: Charmatometrinae), Potamobates anchicaya Polhemus \& Polhemus, 1995 (Gerridae: Cylindrostethinae), Limnogonus hyalinus (Fabricius, 1803), and Tachygerris opacus (Champion, 1898) (Gerridae: Gerrinae).
\end{abstract}

Key words. Aquatic insects, Neotropical Region, semiaquatic bugs, taxonomy

\section{Introduction}

Heteroptera (Insecta: Hemiptera) is a group of insects distributed worldwide, with higher diversity in the tropics (Mazzucconi et al. 2009). Among the seven infraorders that compose the suborder, Gerromorpha and Nepomorpha are intimately related to water bodies on all continents, except for Antarctica (Nieser \& Melo 1997; Polhemus \& Polhemus 2008). Gerromorpha comprises more than 2,100 species of mainly semiaquatic bugs, divided into approximately 160 genera and eight families (Polhemus \& Polhemus 2008; Moreira 2015). The Neotropical fauna is relatively well-known and the second richest in number of described species, only behind the Oriental Region (Polhemus \& Polhemus 2007; Polhemus \& Polhemus 2008).

Descriptions and records of Gerromorpha from Panama are concentrated between the decades of 1890 and 
1950, and the accumulated number of species known from the country has not changed much since then (Tuñon et al. 2015). In contrast, Colombia has records of 33 genera and about 200 species of semiaquatic bugs so far, and knowledge has advanced considerably in recent years, especially due to taxonomic and faunistic studies (e.g., Molano \& Morales 2017; Molano et al. 2017a; Molano et al. 2017b; Mondragón-F. et al. 2017; Padilla-Gil 2017; Castro-Vargas et al. 2018; Molano et al. 2018a; Molano et al. 2018b; Moreno et al. 2018; Floriano et al. 2019; Martínez et al. 2019; Padilla-Gil 2019a; Padilla-Gil 2019b; Polhemus et al. 2019; Morales et al. 2020).

We present here the description of Rhagovelia joceliae Rodrigues \& Moreira, sp. nov. (Veliidae: Rhagoveliinae), based on material recently collected in Panama (Figs 2-22). Additionally, new records from Panama (Figs 1c-1d) and Colombia (Figs 1a-1b) are presented for two species of Mesoveliidae, one species of Hebridae, one species of Hydrometridae, nine species of Veliidae, and six species of Gerridae. Most of the material reported here was collected during an expedition to Colón Province, Panama, but there are also specimens from Panama Province and from the Colombian departments of Amazonas, Boyacá, Caquetá and Cundinamarca.
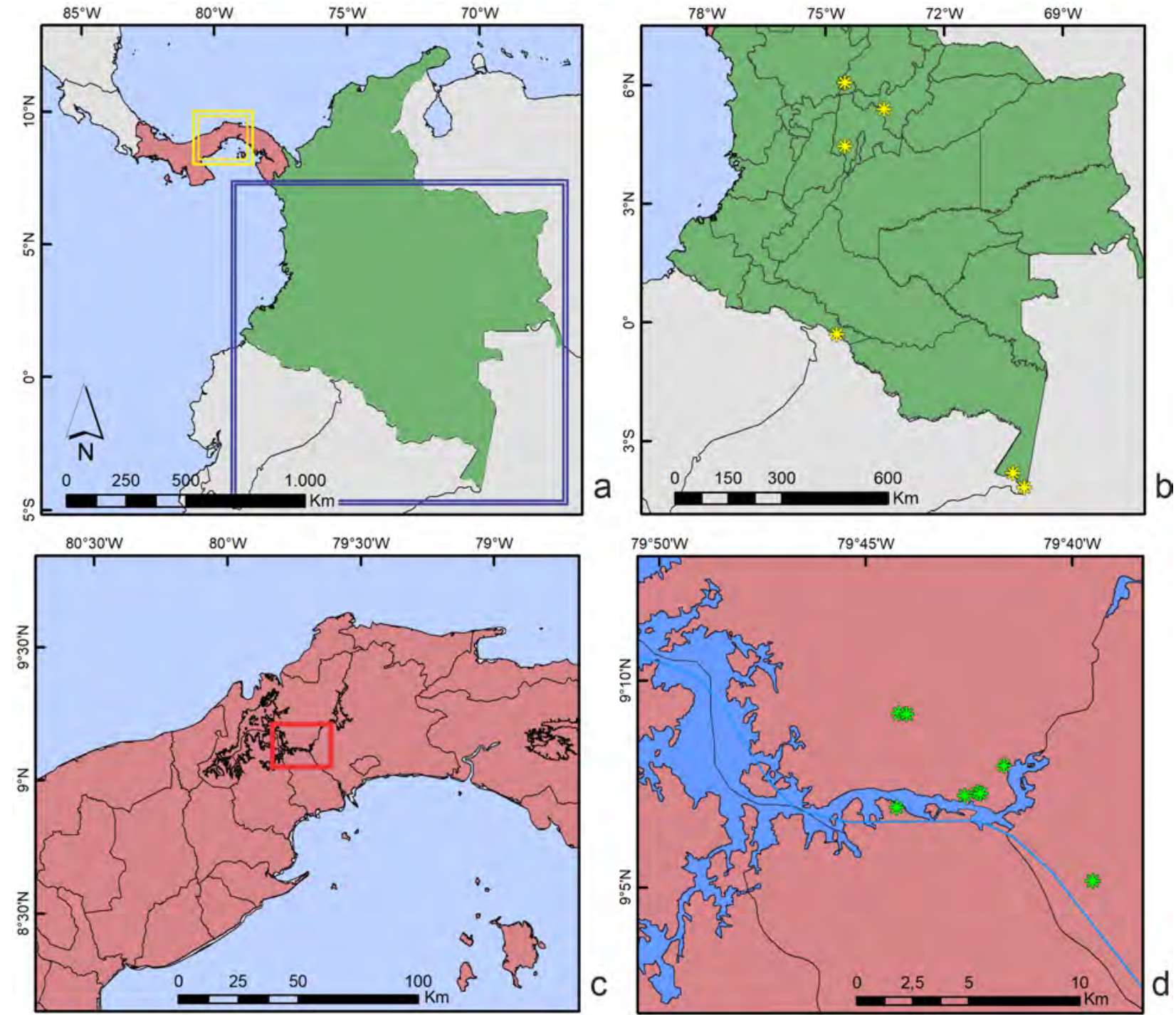

FIGURE 1. Maps with the geographic distribution of the new species and the new records. a, Panamá in pink and Colombia in green; highlights indicate areas enlarged in the next maps. b, Colombia; yellow asterisks indicate the locations where specimens were sampled. c-d, Panamá; green asterisks indicate the locations where specimens were sampled.

\section{Material and methods}

The material examined is deposited in the Entomological Collection of the Oswaldo Cruz Institute, Rio de Janeiro, Brazil (CEIOC), the Colección de Macroinvertebrados Acuáticos, Instituto Amazónico de Investigaciones Científi- 
cas, Leticia, Colombia (COMAC), and the Laboratorio de Entomología, Museo de Historia Natural "Luis Gonzalo Andrade”, Universidad Pedagógica y Tecnológica de Colombia, Tunja, Colombia (UPTC). Additional vouchers have been deposited in the Museo de Invertebrados "Fairchild", Universidad de Panamá (MIUP). Abbreviations of morphological terms are used as follows: body length (BL), head length (HL), head width through the eyes (HW), eye width (EYE), length of antennomeres I-IV [excluding intersegmental pieces] (ANT I, ANT II, ANT III, ANT IV), pronotal length (PL), pronotal width (PW), femoral length (FEM), tibial length (TIB), tarsomere length (TAR I, TAR II, TAR III). All measurements are given in millimeters and were always taken in their maximum dimensions. Geographical coordinates of the collecting localities were obtained with a GPS receiver. Maps were produced using ArcGIS 10.5 .

\section{Results and discussion}

\section{Description}

\section{Rhagovelia joceliae Rodrigues \& Moreira, sp. nov.}

(Figs 2-22)

Type material examined. HOLOTYPE. PANAMA • Apterous male; Colón, Pipeline Road, Seda River; 9.15329 N, -79.73663 W; 6 May 2015; A.J.J. Crumière leg.; CEIOC 79939. ALLOTYPE. PANAMA • apterous female; same data as holotype; CEIOC 79941. PARATYPES. PANAMA • 7 apterous males, 2 macropterous males, 11 apterous females, 1 macropterous female; same data as holotype; CEIOC $79941 \cdot 2$ apterous males, 5 apterous females, 1 macropterous female; Colón, PR, Folijes River; 9.15244 N, $-79.73739^{\circ} \mathrm{W} / 9.15282^{\circ} \mathrm{N},-79.73351^{\circ} \mathrm{W}, 7$ May 2015, A.J.J. Crumière leg.; CEIOC 79942.

Apterous male. Holotype (Figs 2-3) / Paratypes. BL 2.55 / 2.40-2.55, HL 0.27 / 0.20-0.30, HW 0.67 / 0.70 , ANT I 0.56 / 0.50-0.65, ANT II 0.32 /0.30-0.35, ANT III 0.32 / 0.32-0.38, ANT IV 0.38 / 0.37-0.42, EYE 0.20 / 0.20, PL 0.17 / 0.15-0.20, FORELEG: 0,75/ 0.70-0.80, TIB 0.75 / 0.65-0.80, TAR I 0.04 / 0.02-0.04, TAR II 0.02 / 0.02-0.03, TAR III 0.20 / 0.18; MIDLEG: FEM 1.30 / 1.20-1.30, TIB 0.90 / 0.80-0.92, TAR I 0.06 / 0.06-0.08, TAR II 0.36 / 0.34-0.42, TAR III 0.64 / 0.56-0.66; HINDLEG: FEM 1.00 /0.90-1.10, TIB 1.05 /1.00-1.10, TAR I 0.04/ 0.04, TAR II 0.08 / 0.08, TAR III 0.24 / 0.22-0.26.

Head black. Eyes reddish to brown. Antenniferous tubercle dark brown. Proximal half of antennomere I yellow; rest of antenna black. Clypeus brown, buccula and jugum yellowish to brown. Labium yellowish to brown, darker at apex. Pronotum black with a yellowish transverse band on anterior half. Meso- and metanotm black. Proepisternum yellowish brown. Venter of thorax bluish gray. Acetabula yellow. Coxae yellow; mid coxa slightly darker. Fore and hind trochanters light yellow; mid trochanter black. Fore femur yellow on basal third, black towards apex. Mid femur black. Hind femur black, ventrally brown at base. Tibiae and tarsi black. Abdominal medio- and laterotergites black. Abdominal mediotergite V with a small shining black spot at center, VI-VIII with larger shining black spots. Abdominal sterna bluish gray; VII orange to brown centrally. Abdominal segment VIII black dorsally, orange to brown ventrally. Pygophore and proctiger dark brown to black.

Head short, with long black setae anterior to eye and adjacent to mesal eye margin; midline impressed; a pair of oblique indentations on base. Antenna covered by short brown setae; antennomeres I-II with longer, thicker, black setae. Antennomeres I-III cylindrical; I curved; IV fusiform. Labium thick, reaching middle of mesosternum. Thorax dorsally covered by short shining setae, with longer setae on margins. Pronotum short, one third the length of mesonotum; posterior margin concave. Proepisternum, thoracic and abdominal sterna, and mesal area of proacetabulum with black denticles (Fig. 10).

Meso- and metacetabula without black denticles. Legs covered by shining setae, more densely on trochanters, femora, and tibiae; femora and tibiae also with rows of longer, thicker, darker setae. Trochanters without spines. Fore tibia slightly widened distally, weakly concave near apex. Hind femur slightly surpassing the apex of body, slightly incrassate, anterior margin straight, posterior margin slightly sinuous; ventrally with a row of 1 long spine and 3-5 short to medium spines (Fig. 12). Hind tibia straight, with short and long setae; tuft of short setae at the apex; without spinules or apical spur. Dorsum of abdomen covered by short shining setae. Abdominal laterotergites not elevated, gently tapering toward apex. Abdominal sterna with dense median band of moderately long setae; very 
short setae surrounding midline; longer setae on sides and on sterna VI-VII; sternum VII with a pair of depressions adjacent to midline. Proctiger rounded at apex, densely covered by long setae; basal half with moderately long bristles on sides, smooth in the center (Fig. 20). Parameres short, with apical process slightly tapering; shape as in Fig. 21.

Macropterous male (Figs 6-7). BL 2.50-2.55, HL 0.30; HW 0.70-0.75; ANT I 0.62-0.64; ANT II 0.35-0.36; ANT III 0.35; ANT IV 0.40; EYE 0.22-0.25; PL 1.10-1.15; FORELEG: FEM 0.75-0.80; TIB 0.80-0.85; TAR I 0.02; TAR II 0.02-0.03; TAR III 0.18-0.20; MIDLEG: FEM 1.30-1.40; TIB 0.85-0.90; TAR I 0.06; TAR II 0.40-0.44; TAR III 0.62-0.66; HINDLEG, FEM 1.05-1.15; TIB 1.05-1.15; TAR I 0.04; TAR II 0.06-1.00; TAR III $0.24-0.28$.
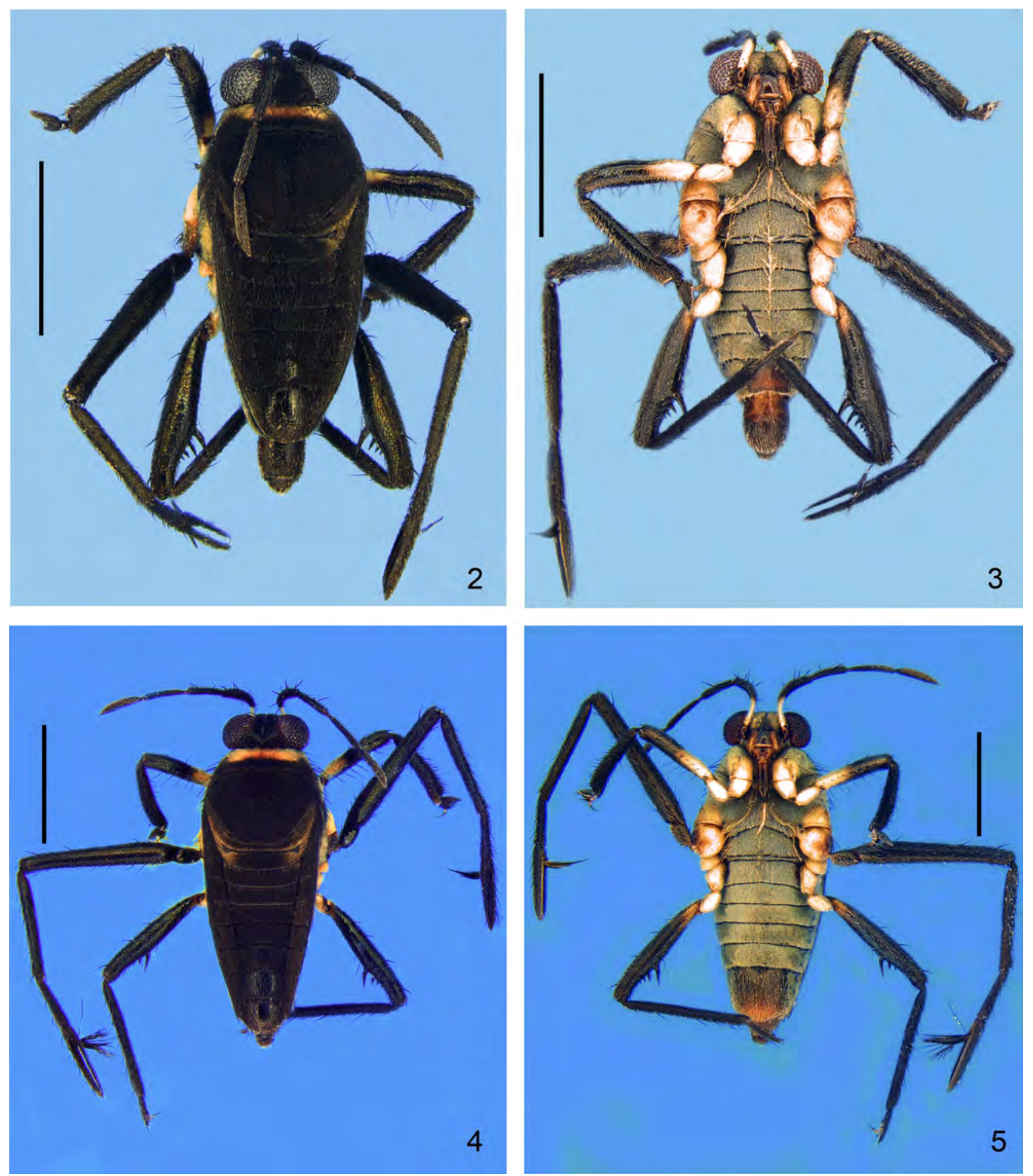

FIGURES 2-5. Rhagovelia joceliae Rodrigues \& Moreira, sp. nov. 2-3, Holotype, apterous male. 2, Dorsal view. 3, Ventral view. 4-5, Paratype, apterous female. 4, Dorsal view. 5, Ventral view. Scale bars: $1.0 \mathrm{~mm}$. 
Coloration and structure similar to apterous male. Pronotum long, completely covering meso- and metanota; posterior margin rounded. Forewings dark brown, with veins dark brown to black and a small yellowish spot at middle; exceeding tip of abdomen and bearing 3 closed cells. Hind femur ventrally with a row of 1 long spine plus 3-6 short to medium spines (Fig. 13). Abdominal sterna II IV with dense median band of moderately long setae; with very short setae surrounding median band; longer setae on sides and in abdominal sterna VI VII.
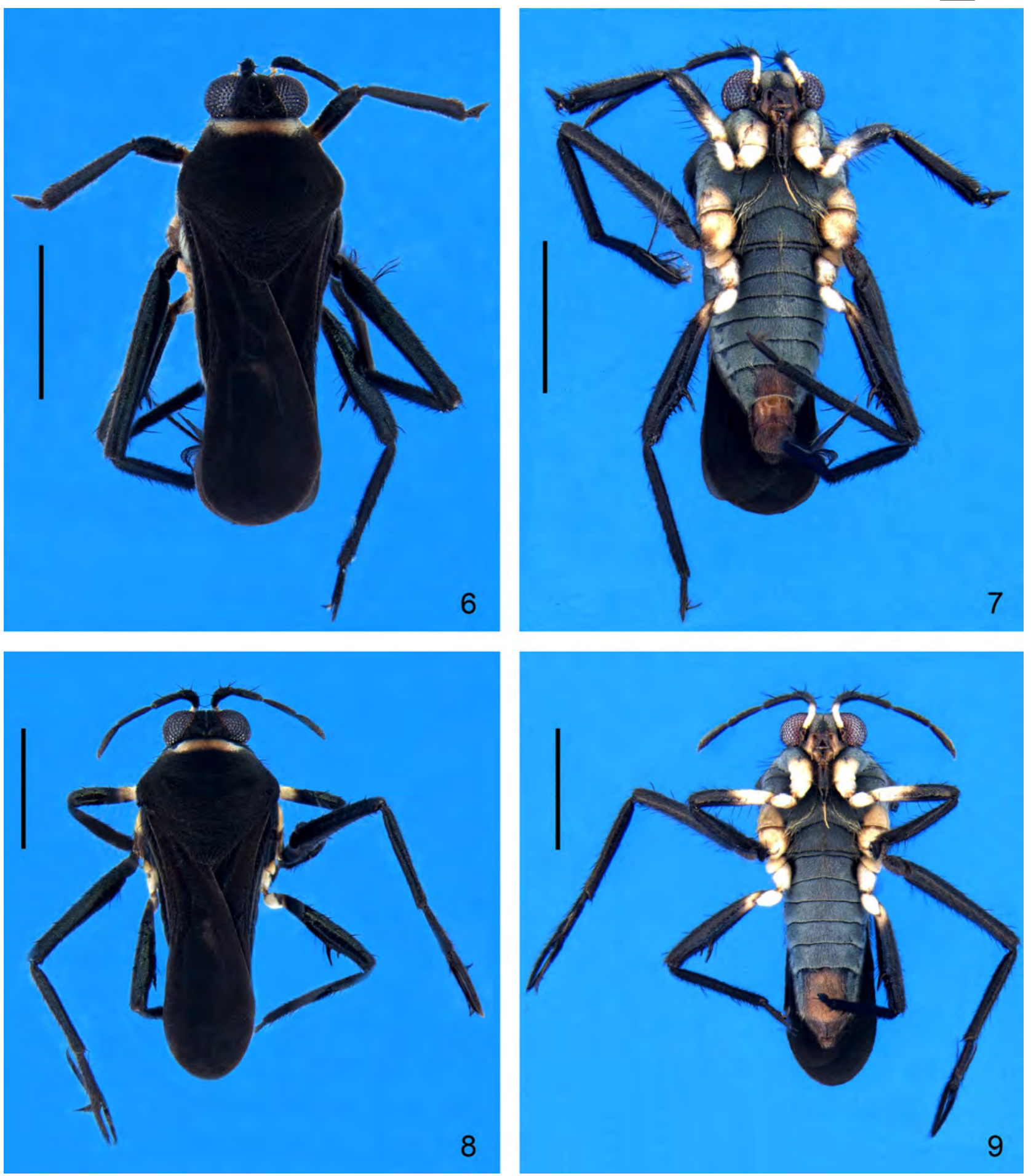

FIGURES 6-9. Rhagovelia joceliae Rodrigues \& Moreira, sp. nov. 6-7, Paratype, macropterous male. 6, Dorsal view. 7, Ventral view. 8-9, Paratype, macropterous female. 8, Dorsal view. 9, Ventral view. Scale bars: $1.0 \mathrm{~mm}$. 

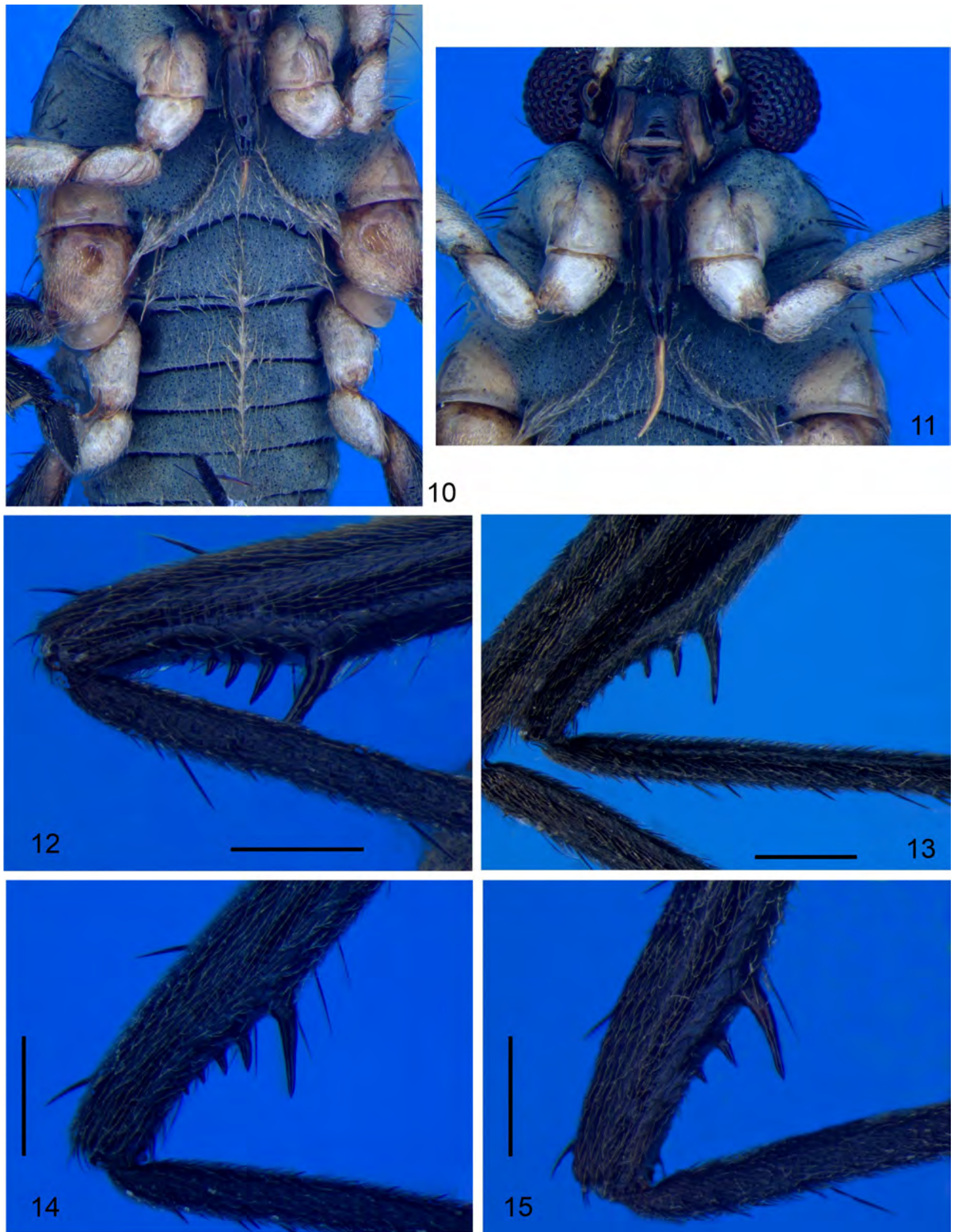

FIGURES 10-15. Rhagovelia joceliae Rodrigues \& Moreira, sp. nov. 10-11, Ventral view, part of labium, thoracic and abdominal sterna, acetabulae and coxae. 10, Holotype male. 11, Paratype female. 12-15, Hind femur with a row of one long spine and several short to medium spines. 12, Holotype, apterous male; 13, Paratype, macropterous male; 14, paratype, apterous female; 15, paratype, macropterous female. Scale bars: $0.2 \mathrm{~mm}$. 

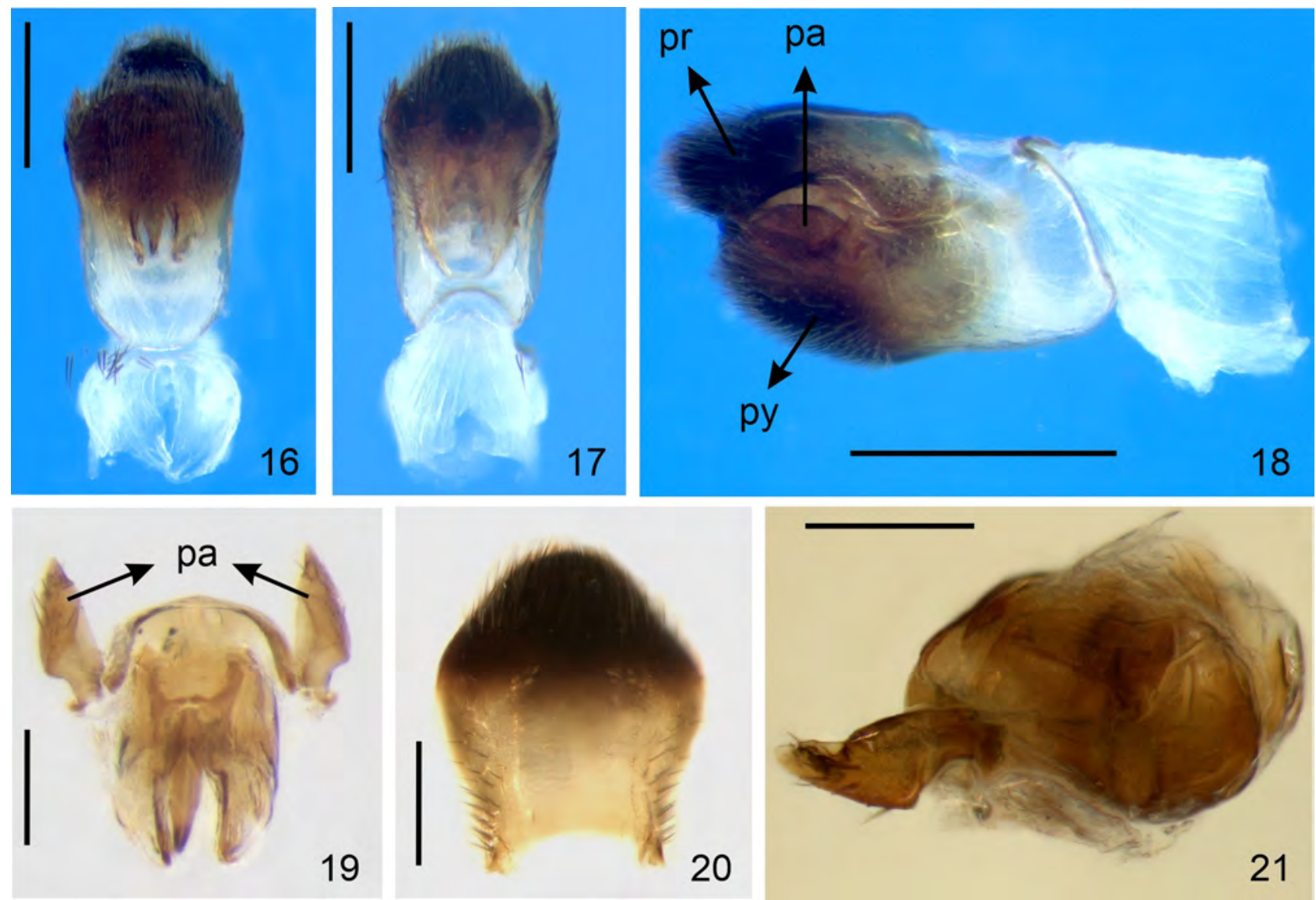

FIGURES 16-21. Rhagovelia joceliae Rodrigues \& Moreira, sp. nov.; male terminalia. 16-20, Genital capsule. 16, Ventral view. 17, Dorsal view. 18, Lateral view. 19, paramere; pr, proctiger; py, pygophore). Scale bars: $0.2 \mathrm{~mm}$ (16-19), $0.1 \mathrm{~mm}$ (20-21).

Apterous female (Figs 4-5). BL 2.70-2.90, HL 0.25-0.30; HW 0.70-0.80; ANT I 0.55-0.80; ANT II 0.300.35; ANT III 0.30-0.35; ANT IV 0.35-0.40; EYE 0.20-0.30; PL 0.15-0.20; FORELEG: FEM 0.70-0.72; TIB 0.70-0.75; TAR I 0.20; TAR II 0.02; 0.18-0.20; MIDLEG: FEM 1.25-1.35; TIB 0.65-0.90; TAR I 0.04-0.08; TAR II 0.34-0.40; TAR III 0.56-0.68; HINDLEG, FEM 1.00-1.07; TIB 0.90-1.10; TAR I 0.04-0.06; TAR II 0.08-0.10; TAR III 0.24-0.26.

Coloration and structure similar to apterous male. Abdominal mediotergite V with small shining black spot at middle (absent in some specimens), VI-VIII with larger shining black spots. Hind femur almost reaching apex of body; ventrally with a row of 1 long spine plus 3-5 short to medium spines (Fig. 14). Abdominal laterotergites slightly elevated, tapering toward apex. Abdominal sterna II-IV with median band of moderately long setae (absent in some specimens); thery short setae centlly; longer setae on sides and on sterna VI-VII; sternum VII without pair of depressions adjacent to midline.

Macropterous female (Figs 8-9). BL 2.80-2.95; HL 0.30; HW 0.75-0.80; ANT I 0.55-0.70; ANT II 0.35; ANT III 0.35; ANT IV 0.40; EYE 0.25-0.30; PL 1.10-1.15; FORELEG: FEM 0.70-0.75; TIB 0.75-0.80; TAR I 0.03; TAR II 0.02; TAR III 0.18; MID LEG: FEM 1.20-1.35; TIB 0.85; TAR I 0.08; TAR II 0.42; TAR III 0.64; HIND LEG, FEM 1.00-1.10; TIB 1.10; TAR I 0.04; TAR II 0.10; TAR III 0.20.

Coloration and structure similar to macropterous male, except for the following: hind femur ventrally with a row of 1 long spine plus $2-5$ short to medium spines (Fig. 15).

Remarks. Rhagovelia joceliae Rodrigues \& Moreira, sp. nov. is part of the angustipes complex of species, based on the pronotum of the apterous form shorter on the midline than the dorsal length of the eye, with the posterior margin concave (Polhemus 1997). It can be distinguished from similar species by the abundant black denticles present on the venter of the body (Figs 9 (10), which are usual in some of the other complexes of American Rhagovelia, but not in the angustipes complex. 
The new species can also be diagnosed by the following combination of characters: body short (2.40-2.95 mm, including both sexes and wing morphs); acetabula yellow (Figs. 3, 10); coxae yellow, mid coxa slightly darker (Figs. 3, 10); fore and hind trochanters light yellow, mid trochanter black (Fig. 3); abdominal mediotergite V with a small shining black spot at middle, VI-VIII with larger shining black spots (Fig. 2); males with hind femur slightly surpassing the apex of body, ventrally with a row of 1 long spine plus 3-6 short to medium spines (Figs 12-13); hind tibia straight, without spinules or apical spur; females with hind femur almost reaching apex of body, ventrally with a row of 1 long spine plus 3-5 short to medium spines (Figs 14-15); and abdominal laterotergites in both sexes slightly elevated, tapering toward apex (Figs 2, 4).

Rhagovelia tantilla Drake \& Harris, 1933 is most similar to $R$. joceliae Rodrigues \& Moreira, sp. nov., but the former is larger (2.86-3.66 mm, including both sexes and wing morphs), lacks black denticles on the venter of the body, usually has shining black areas only on abdominal mediotergites VII-VIII (rarely V-VIII in the female), and has completely different parameres (Bacon 1956: Fig. 16).

Rhagovelia joceliae Rodrigues \& Moreira, sp. nov. was collected together with one congener, $R$. elegans, and four other species of Gerromorpha in the Seda River, namely Microvelia albonotata, Potamobates anchicaya, Brachymetra albinervus and Tachygerris opacus. This creek is shadowed and mostly covered by trees; M. albonotata was collected close to the margins and the gerrids were mostly on calm water, sometimes accompanied by the Rhagovelia. In the Folijes River, the new species co-occurred with another congener, $R$. rosensis, plus Metrobates laudatus, Telmatometra ujhelyii and P. anchicaya. This calm creek is composed of alternate sunny and shadowed patches; Rhagovelia were usually caught close to the margin, while the gerrids were located on open water.

Etymology. The specific epithet is given in honor of Prof. Dr. Jocélia Grazia, Brazilian entomologist, in recognition of her important contributions to the knowledge of Neotropical Heteroptera.

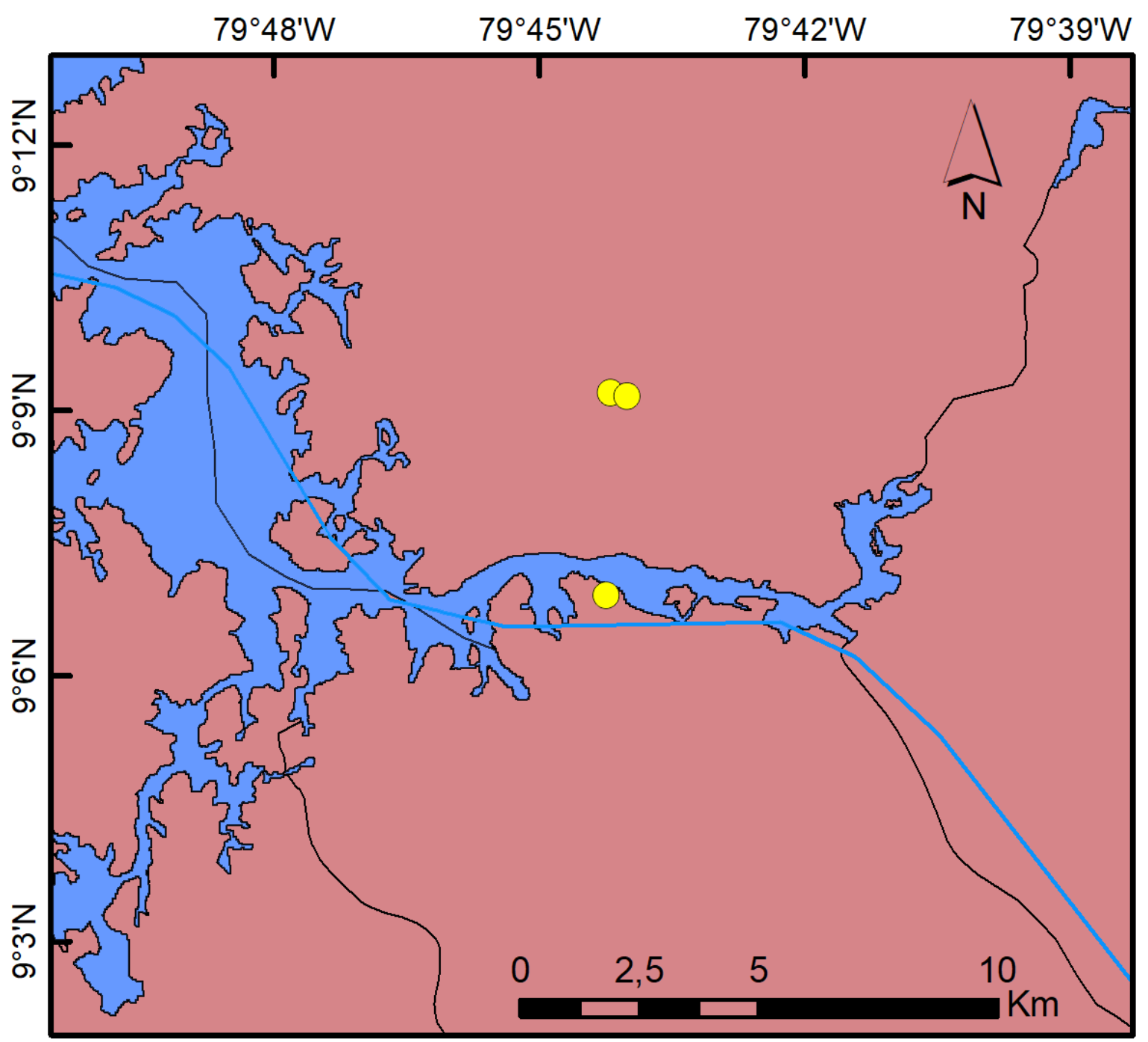

FIGURE 22. Distribution of Rhagovelia joceliae Rodrigues \& Moreira, sp. nov. in Panama indicated by yellow circles. 


\section{New records}

\section{Mesoveliidae: Mesoveliinae}

\section{Mesovelia mulsanti White, 1879}

(Figs 23, 33)

New records. PANAMA • 4 apterous males, 4 apterous females; Colón, Gamboa, Río Chagres; 9.13219 N, 79.69418 W; 8 May 2015; A.J.J. Crumière leg.; CEIOC 79921. • 6 apterous males, 10 apterous females; Colón, Gamboa, artificial pool; 9.12086 N, -79.70374 W; 9 May 2015; A.J.J. Crumière leg.; CEIOC 79919.

Remarks. This is the most common and widespread species of the genus in the Americas, ranging from Canada to Argentina, besides having been introduced in the Hawaiian Islands (Damgaard et al. 2012). There is only one previous record from Panama (Champion 1898), from near Panama City. The record above is the first from Colón Province. Río Chagres is a large river, where the mesoveliids were collected moving on top of hydrophytes with large leaves that almost totally covered the surface of the water in the sampled area. The artificial pool where Mes. mulsanti was collected had a fair diversity of semiaquatic bugs. In addition to this species, Lipogomphus leucostictus, Platyvelia brachialis, Microvelia fantastika, Mi. mimula and Limnogonus hyalinus have been collected in the same habitat. The pool occupies about $40 \mathrm{~m}^{2}$ under some trees, and was massively covered by hydrophytes with minute leaves, with almost no open water.

\section{Mesovelia zeteki Harris \& Drake, 1941}

(Figs 24, 33)

New records. PANAMA 11 apterous male; Colón, PR, creek close to Folijes River; 9.12086 N, $-79.70374^{\circ}$ W, 7 May 2015, A.J.J. Crumière leg.; CEIOC 79922.

Remarks. Mesovelia zeteki has been reported from Panama, Colombia and northern Brazil (Damgaard et al. 2012, Floriano et al. 2016). The record above is the second from Colón Province. This species was collected in water pools remaining from a dry creek.
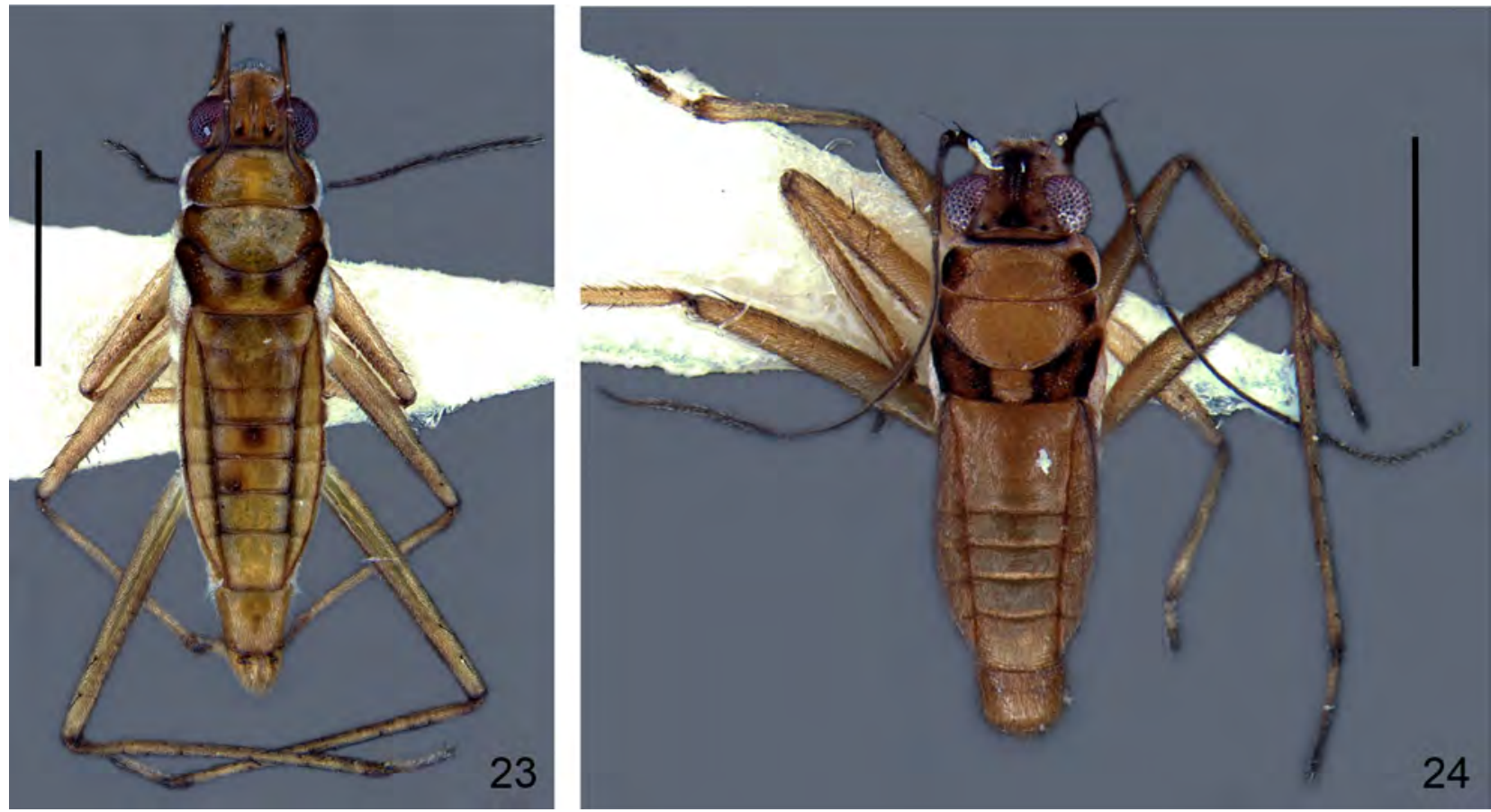

FIGURES 23-24. Habitus, dorsal view. 23, Mesovelia mulsanti White, 1879. 24, Mes. zeteki Harris \& Drake, 1941. Scale bars: $1.0 \mathrm{~mm}$ 


\section{Hebridae: Hebrinae}

\section{Lipogomphus leucostictus (Champion, 1898)}

(Figs 25, 34)

New records. PANAMA 1 macropterous male, 1 macropterous female; Colón, Gamboa, artificial pool; 9.12086 N, -79.70374 W; 9 May 2015; A.J.J. Crumière leg.; CEIOC 79943.

Remarks. This Central American species has been reported in the literature only a few times (Champion 1898, Drake \& Chapman 1958, Pacheco-Chaves et al. 2014), including a record from Panama without further details (Drake \& Chapman 1958) that is herein confirmed.

\section{Hydrometridae: Hydrometrinae}

\section{Hydrometra caraiba Guérin-Méneville, 1857}

(Figs 26, 34)
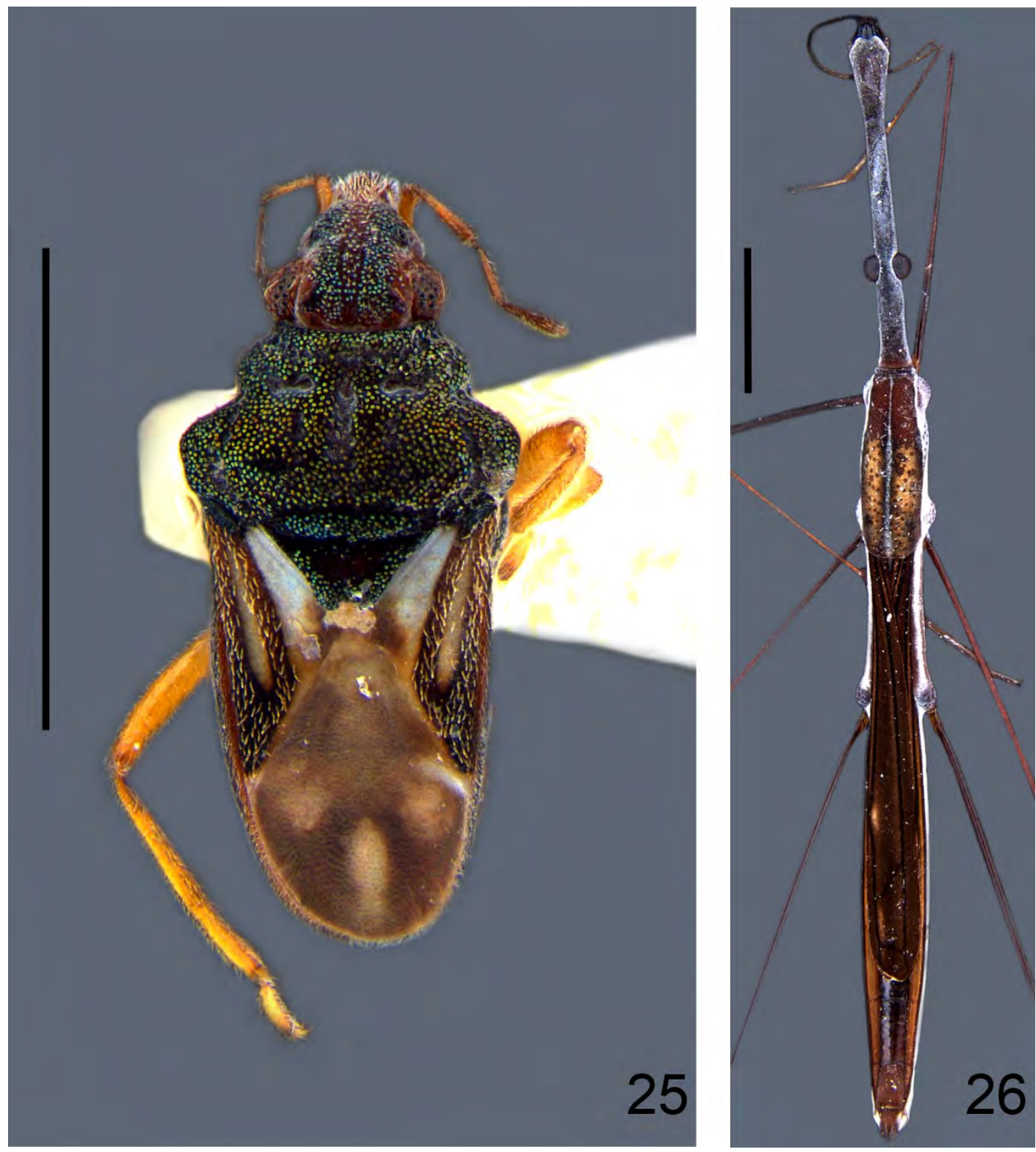

FIGURES 25-26. Habitus, dorsal view. 25, Lipogomphus leucostictus (Champion, 1898). 26, Hydrometra caraiba GuérinMéneville, 1857. Scale bars: 1.0 mm (25), 2.0 mm (26). 
New records. PANAMA • 1 macropterous male; Colón, first creek on Pipeline Road; 9.11917 N, - $79.70609^{\circ}$ W, 7 May 2015, A.J.J. Crumière leg.; CEIOC 79938 • 2 macropterous males, 1 macropterous female; Colón, first creek on Pipeline road; $9.11917^{\circ}$ N, -79.70609 W; 10 May 2015; A.J.J. Crumière leg.; CEIOC 79936.

Remarks. Hydrometra caraiba has been recorded from Mexico to western South America, as well as from several islands of the Caribbean Sea (Martínez et al. 2019). There are only two previous reports from Panama (Champion 1898), from Chiriquí and Panama provinces. Here, we record it for the first time from Colón Province. Specimens were collected adjacent to and on the unvegetated rocky shores of a calm, shadowed creek.

\section{Veliidae: Veliinae}

\section{Platyvelia brachialis Stål, 1860}

(Figs 27, 34)

New records. PANAMA • 3 apterous males; Colón, Gamboa, artificial pool; 9.12086 N, -79.70374 W; 9 May 2015; A.J.J. Crumière leg.; CEIOC 79944.

Remarks. This species has the widest distribution in the genus, ranging from eastern United States to northern Argentina (Floriano et al. 2017). There are a couple of previous reports from Panama Province in Panama (Champion 1898, Allee \& Torvik 1927), and the record above is the first from Colón Province.

\section{Stridulivelia (Stridulivelia) raspa (Hungerford, 1929)}

\section{(Figs 28, 35)}

New records. COLOMBIA -2 apterous males; Amazonas: Lago Pozo Hondo (IV), principal lago de Yaguarcaca; 4¹0'53.1”'N 6957’57.8’W; M. Leython leg.; COMAC.

Remarks. This species was previously known only from Amazonas State, in Brazil (Floriano et al. 2017). The record above is the first from Colombia.
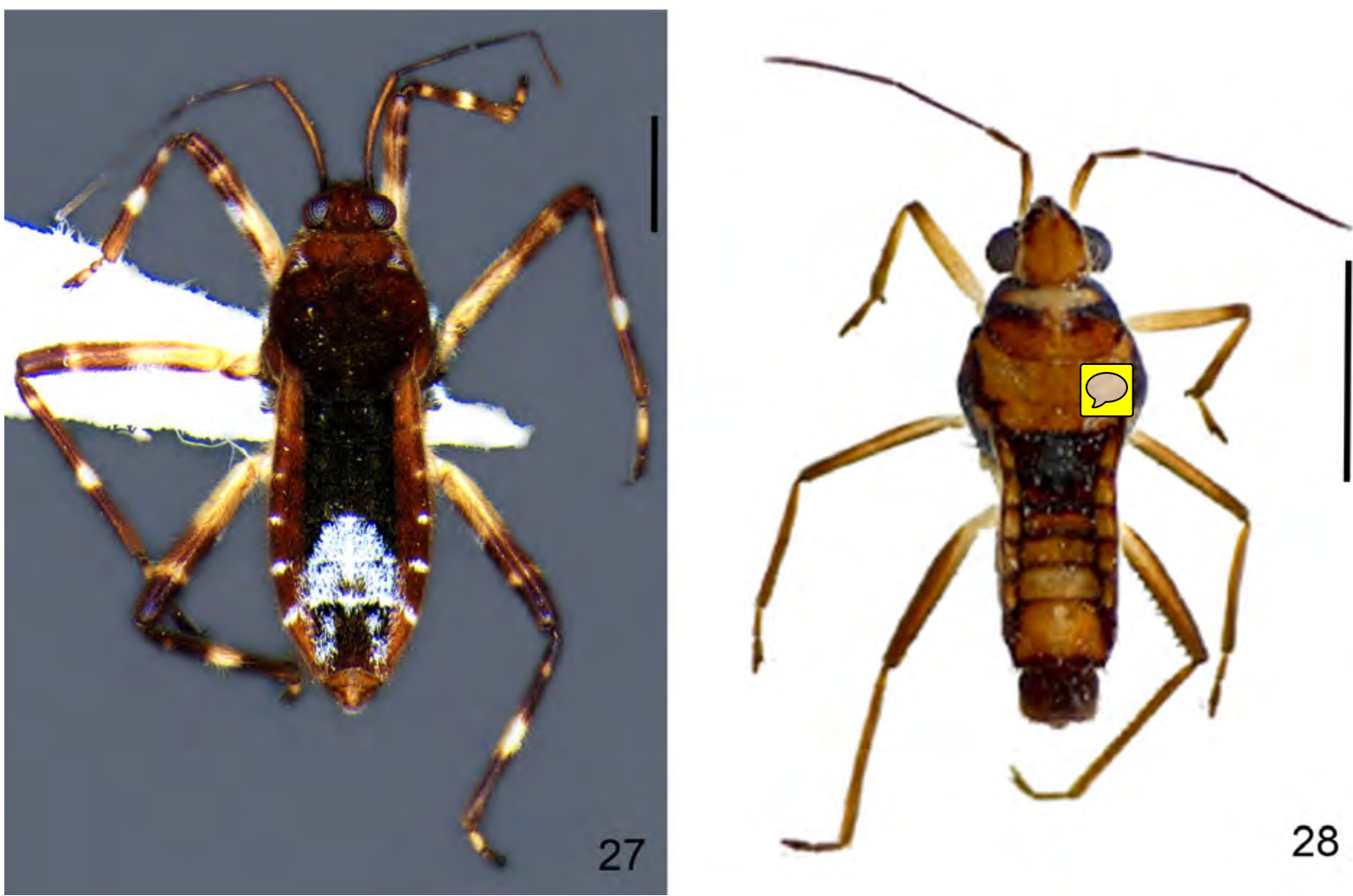

FIGURES 27-28. Habitus, dorsal view. 27, Platyvelia brachialis (Stål, 1860). 28, Stridulivelia (Stridulivelia) raspa (Hungerford, 1929). Scale bars: $1.0 \mathrm{~mm}$. 


\section{Veliidae: Rhagoveliinae}

\section{Rhagovelia elegans Uhler, 1894}

(Figs 29-30, 36)
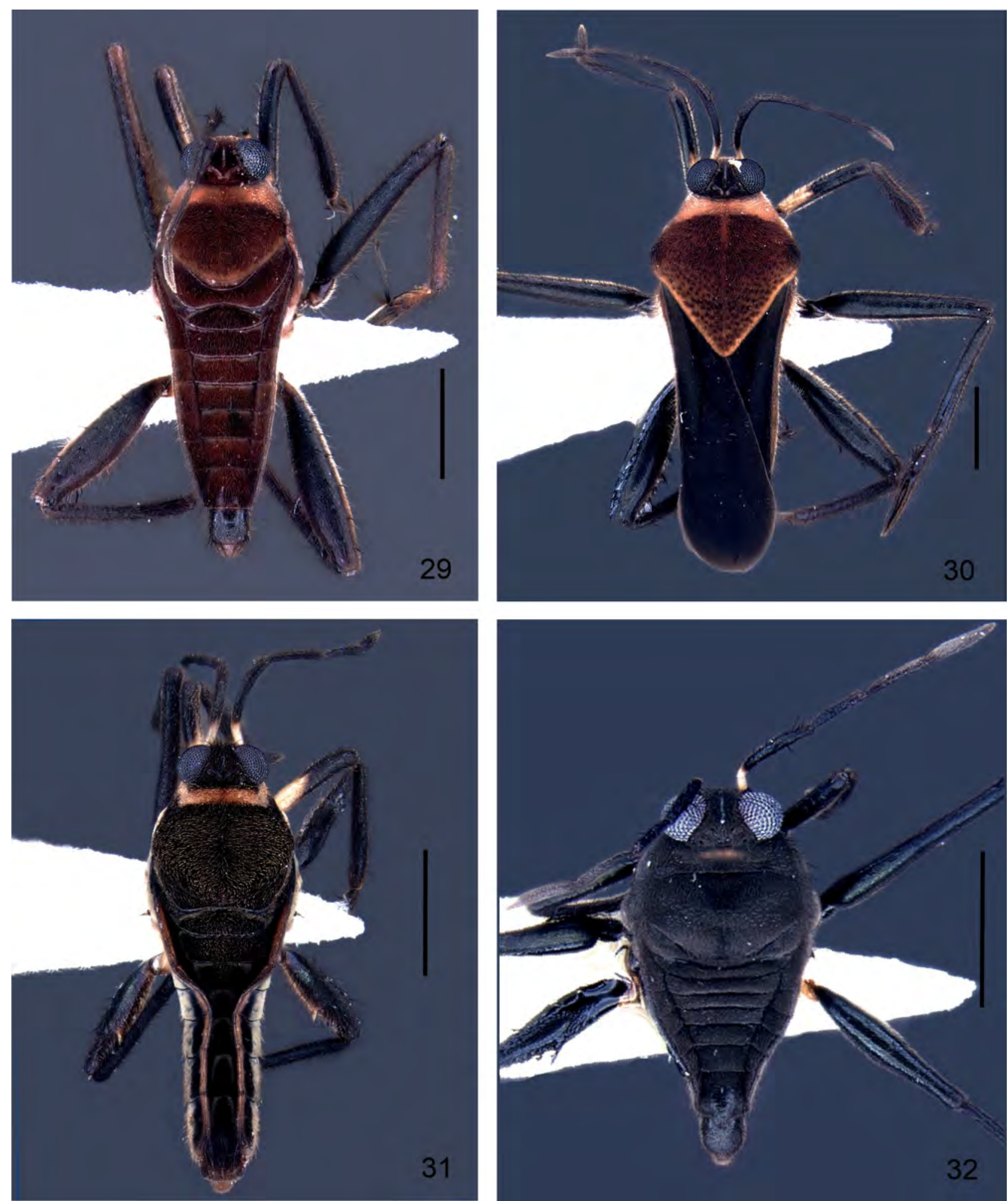

FIGURES 29-32. Habitus, dorsal view. 29-30, Rhagovelia elegans Uhler, 1894. 29, Apterous. 30, Macropterous. 31, R. perija Polhemus, 1997. 32, R. rosensis Padilla-Gil, 2011. Scale bars: $1.0 \mathrm{~mm}$.

New records. PANAMA -3 apterous males, 8 macropterous males, 8 macropterous females; Colón, Gamboa; 9.12117 N, -79.70480 W; 8 May 2015; A.J.J. Crumière leg.; CEIOC 79929 • 2 macropterous males; Colón, 
puddle on Pipeline Road; 9.11917 N, -79.70609 W; 10 May 2015; A.J.J. Crumière leg.; CEIOC 79934 • 2 apterous males, 2 macropterous females; Colón, Pipeline Road, Seda River; 9.15329 N, -79.73663 W; 6 May 2015; A.J.J. Crumière leg.; CEIOC 79932 - 1 macropterous male, 1 macropterous female; Panama, Plantation Road, dry creek, puddle; 9.08556 N, -79.65841ํ W; 17 May 2015; A.J.J. Crumière leg.; CEIOC 79931.

Remarks. This species occurs from Hispaniola Island to Trinidad \& Tobago in the Antilles, and from Costa Rica to southeastern Brazil (Moreira et al. 2016). There are several previous records from Panama (Champion 1898; Allee \& Trovik 1927; Gould 1931; Drake 1948; Bacon 1956; Polhemus 1997), including the provinces of Bocas del Toro, Panama, and Coclé. The records from Colón above are the first from this province. The puddle on the muddy Pipeline Road is quite unstable and the specimens likely moved to this habitat from the surrounding creeks. The specimens from Gamboa were collected in small water pools remaining from a dry creek located under canopy. The water level was very low and it was the only species of Gerromorpha present.
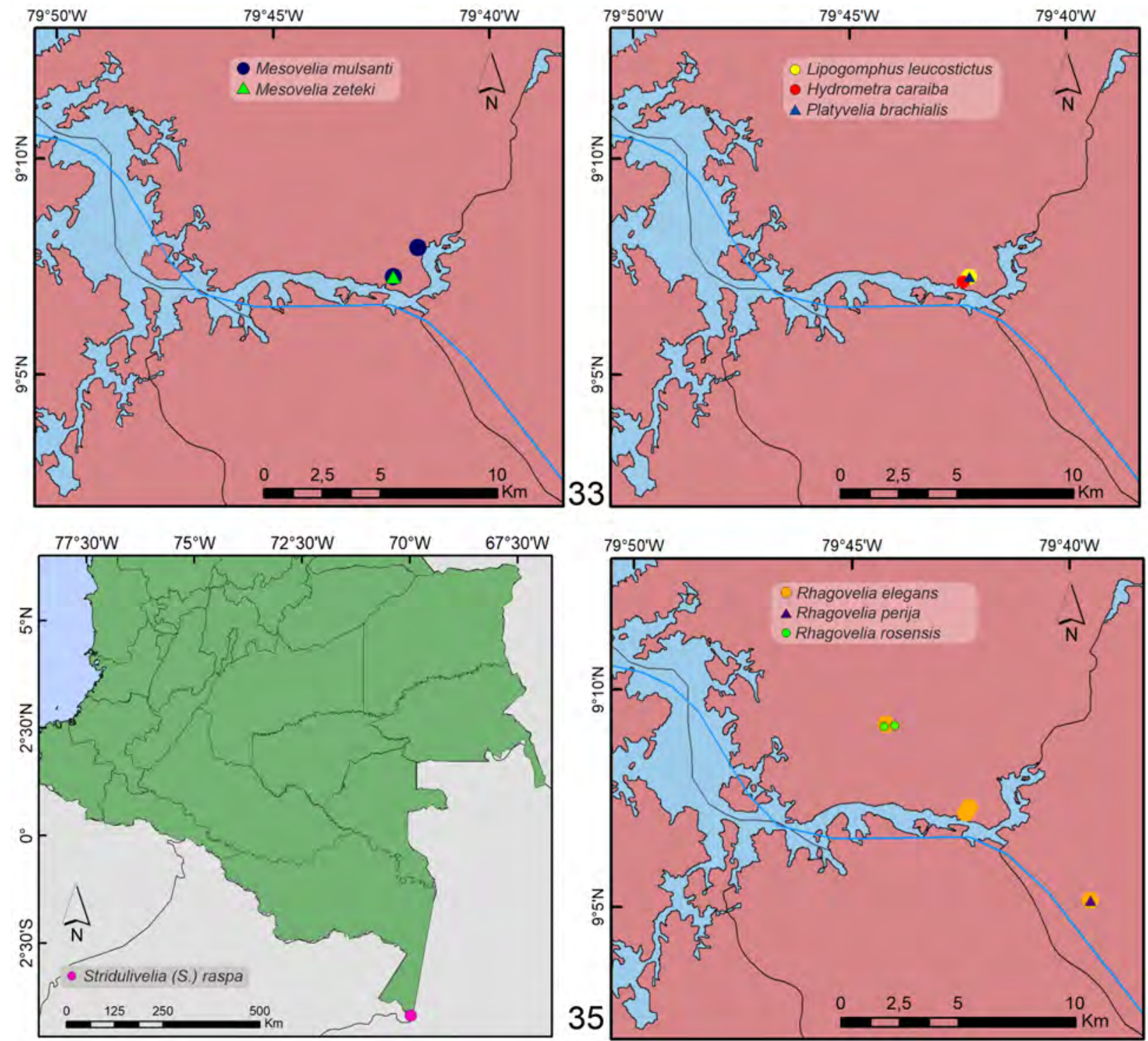

FIGURES 33-36. Distribution of new records from Panamá. 33, Mesovelia mulsanti White, 1879 in blue circles; M. zeteki Harris \& Drake, 1941 in green triangle. 34, Lipogomphus leucostictus (Champion, 1898) in yellow circle; Hydrometra caraiba Guérin-Méneville, 1857 in red circle; Platyvelia brachialis (Stål, 1860) in blue triangle. 35, Stridulivelia (Stridulivelia) raspa (Hungerford, 1929) in pink circle. 36, Rhagovelia elegans Uhler, 1894 in orange hexagon; R. perija Polhemus, 1997 in purple triangle; $R$. rosensis Padilla-Gil, 2011 in green circles. 


\section{Rhagovelia perija Polhemus, 1997}

(Figs 31, 36)

New records. PANAMA 11 apterous male, 1 apterous female; Panama, Plantation Road, dry creek, puddle; $9.08556^{\circ}$ N, -79.65841ํW; 17 May 2015; A.J.J. Crumière leg.; CEIOC 79930.
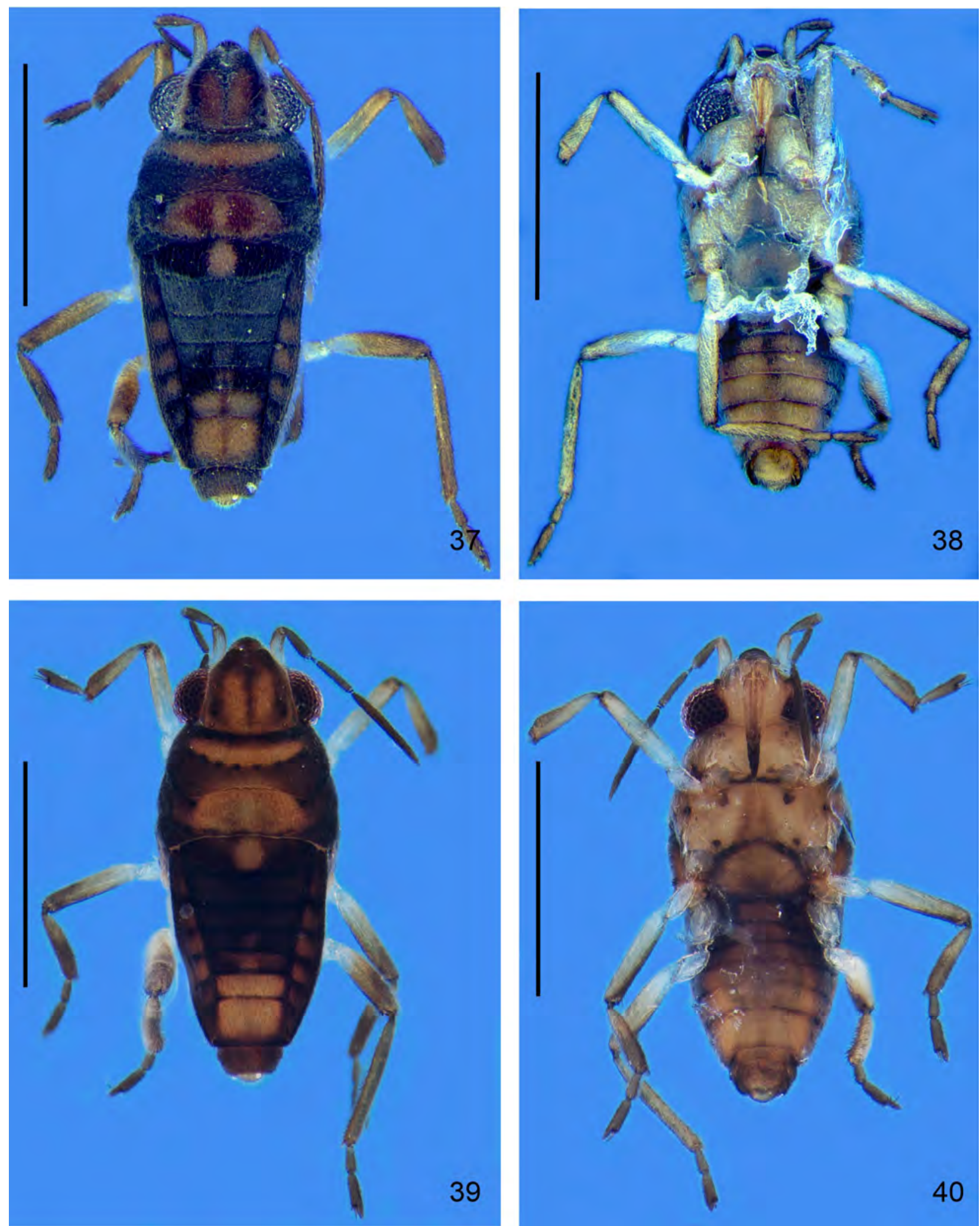

FIGURES 37-40. Microvelia fantastika Padilla-Gil, 2019; male from Panamá. 37-38, dry specimen. 37, Dorsal view. 38, Ventral view. 39-40, Wet specimen. 39, Dorsal view. 40, Ventral view. Scale bars: $0.5 \mathrm{~mm}$. 
Remarks. Rhagovelia perija was described from the Perija Mountain Range, northern Colombia (Polhemus 1997), and subsequently recorded from Quindío (Cobos-Vallejo et al. 2007) and Santander (Aristizábal-García 2017) departments in the same country. We present here the first record of this species from Panama. Rhagovelia elegans and Tachygerris opacus have been collected in the same pools remaining from a dry creek as R. perija.
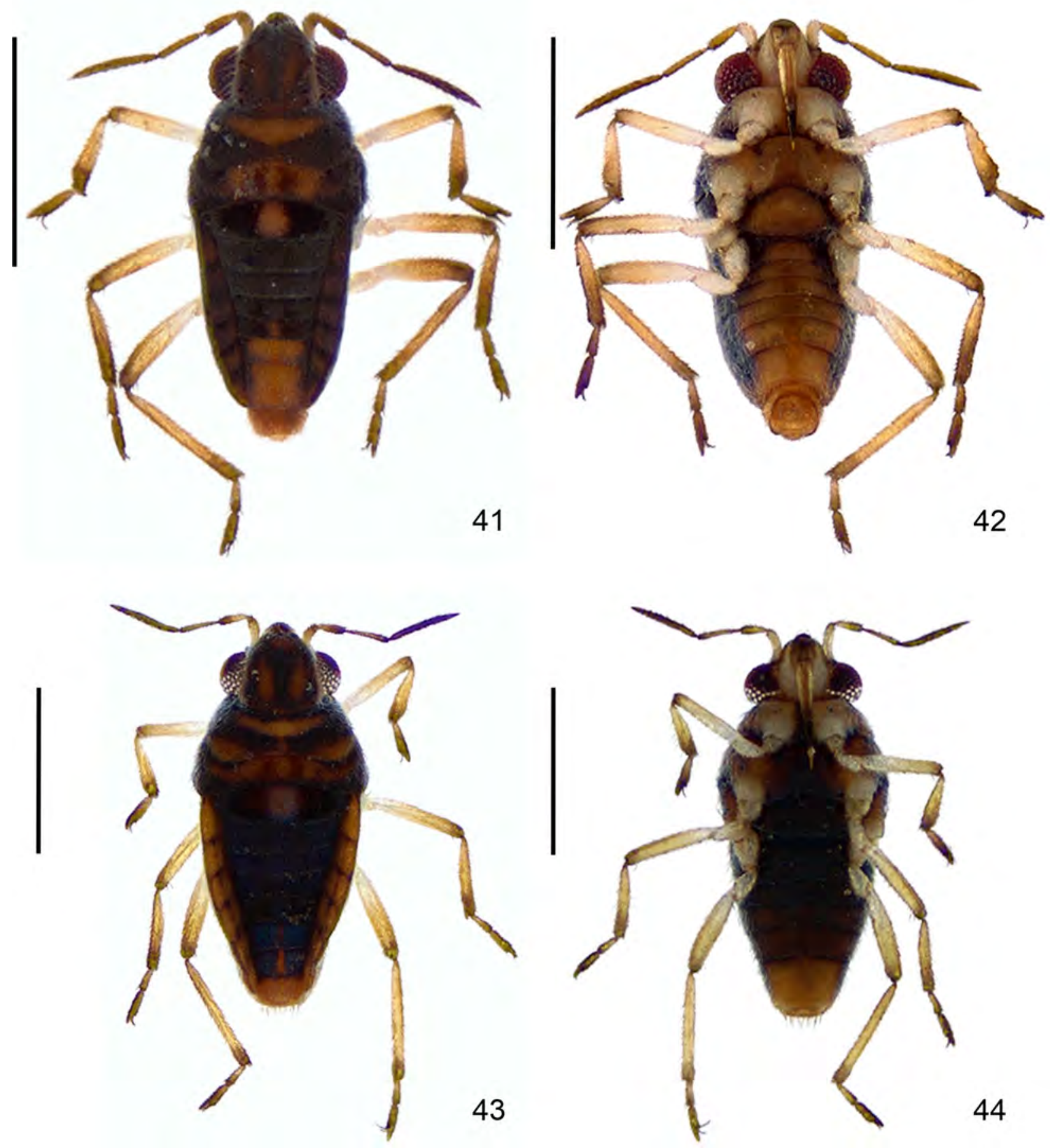

FIGURES 41-44. Microvelia fantastika Padilla-Gil, 2019 from Boyacá, Colombia. 41-42, Male. 41, Dorsal view. 42, Ventral view. 43-44, Female. 43, Dorsal view. 44, Ventral view. Scale bars: $0.5 \mathrm{~mm}$.

\section{Rhagovelia rosensis Padilla-Gil, 2011}

(Figs 32, 36)

New records. PANAMA • 6 apterous males, 1 macropterous male, 4 apterous females; Colón, PR, Folijes River;

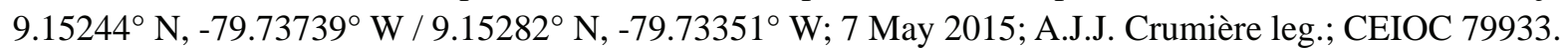


Remarks. This species was described from Nariño Department (Padilla-Gil 2011) and later recorded from Tolima Department (Parra-Trujillo et al. 2014), both in western Colombia. We present here its first record from Panama.
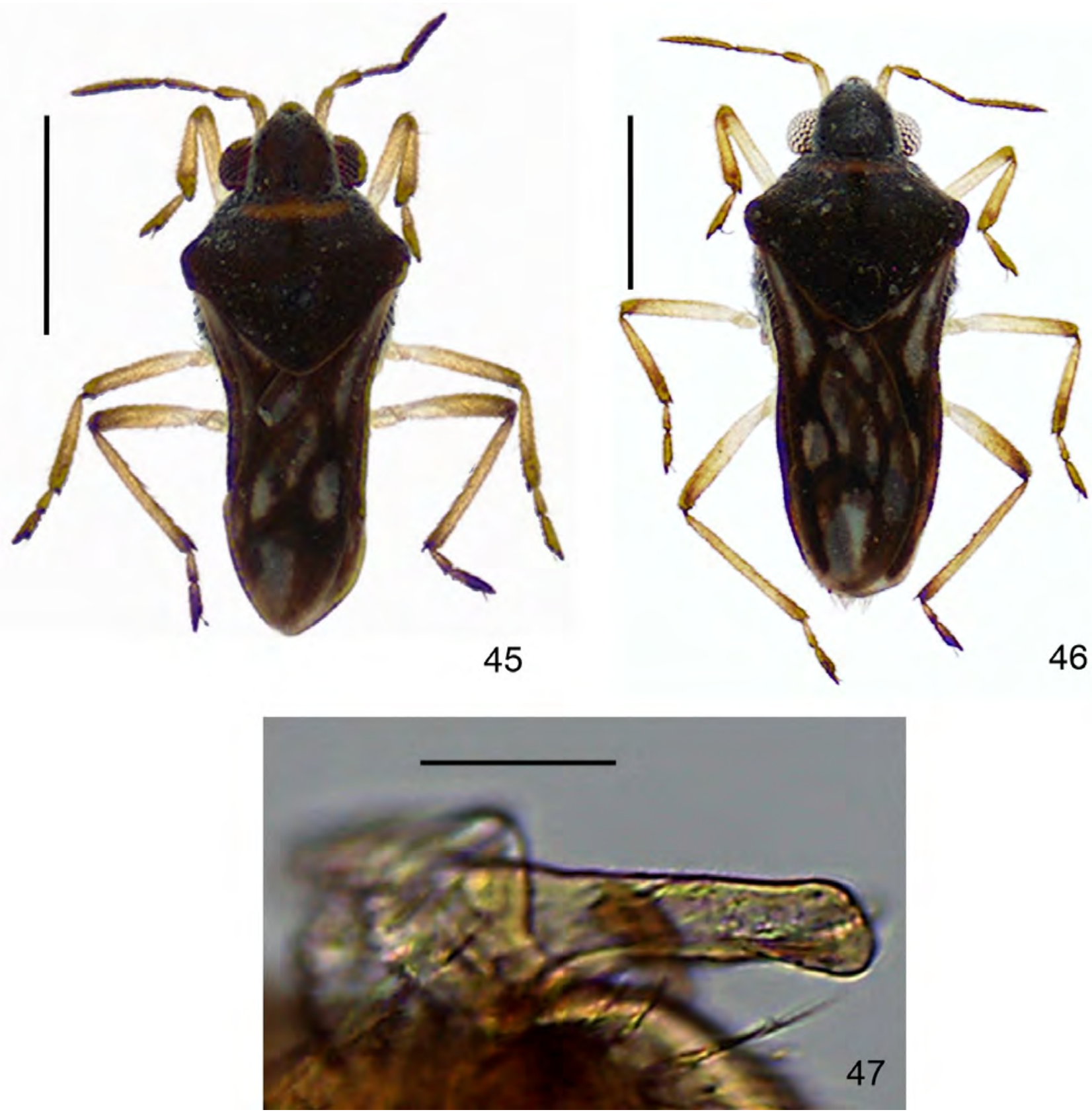

FIGURES 45-47. Microvelia fantastika Padilla-Gil, 2019 from Boyacá, Colombia. 45-46, macropterous specimens. 45, Male, dorsal view. 46, Female, dorsal view. 47, Left paramere, lateral view. Scale bars: 0.5 mm (45-46), 50 Hm (47).

\section{Veliidae: Microveliinae}

\section{Microvelia albonotata Champion, 1898}

(Figs 49, 52-53)

New records. PANAMA • 1 macropterous male; Colón, Pipeline Road, Seda River; 9.15329 N, -79.73663 W; 7 May 2015; A.J.J. Crumière leg.; CEIOC 79926 • 2 macropterous males, 1 macropterous female; Colón, Pipeline Road; 9.15329 N, -79.73663 W; 6 May 2015; A.J.J. Crumière leg.; CEIOC 79925. • COLOMBIA • 11 macropterous males, 1 macropterous female; Boyacá, Togui, Vereda Centro; 23 Oct 2016; F.F.F. Moreira leg.; UPTC • 7 
apterous males, 2 macropterous males, 6 apterous females, 6 macropterous females; Cundinamarca, Viotá, vereda Guasimales, Reserva Natural Camino Verde; 10 May 2017; I. Morales leg.; UPTC 17466.

Remarks. Microvelia albonotata is distributed from eastern North America to Peru (Smith 1988) but reports from Central and South America are scarce and usually poorly detailed (e.g., Drake \& Hussey 1955). There is one previous record from Panama without any further information (Drake \& Hussey 1951), which is herein confirmed. We also present here the first record of this species from Colombia.

\section{Microvelia fantastika Padilla-Gil, 2019}

(Figs 37-48)

New records. PANAMA • Apterous male; Colón, Gamboa, artificial pool; 9.12086 N, -79.70374 W; 9 May 2015; A.J.J. Crumière leg.; CEIOC $79942 \cdot$ COLOMBIA 11 apterous male, 2 apterous female, 1 macropterous female; Boyacá, Puerto Boyacá, Vereda Muelle Velásquez, Ciénaga de Palagua, CC2; 145 m, 6.065 N, -74.510 W; 8 Nov 2019, S.P. Mondragón leg.; UPTC • 4 apterous males, 5 apterous females, 1 macropterous male; Boyacá, Puerto Boyacá, Vereda Muelle Velásquez, Ciénaga de Palagua, CC2; 148 m, 6.066 N, -74.512; 2 W; Dic 2019, S.P. Mondragón leg.; UPTC • 1 macropterous male, 2 apterous females; Boyacá, Puerto Boyacá, Vereda Muelle Velásquez, Ciénaga de Palagua, CC3; 148 m, 6.065 N, -74.508 W, 3 Nov 2019, S.P. Mondragón leg.; UPTC.
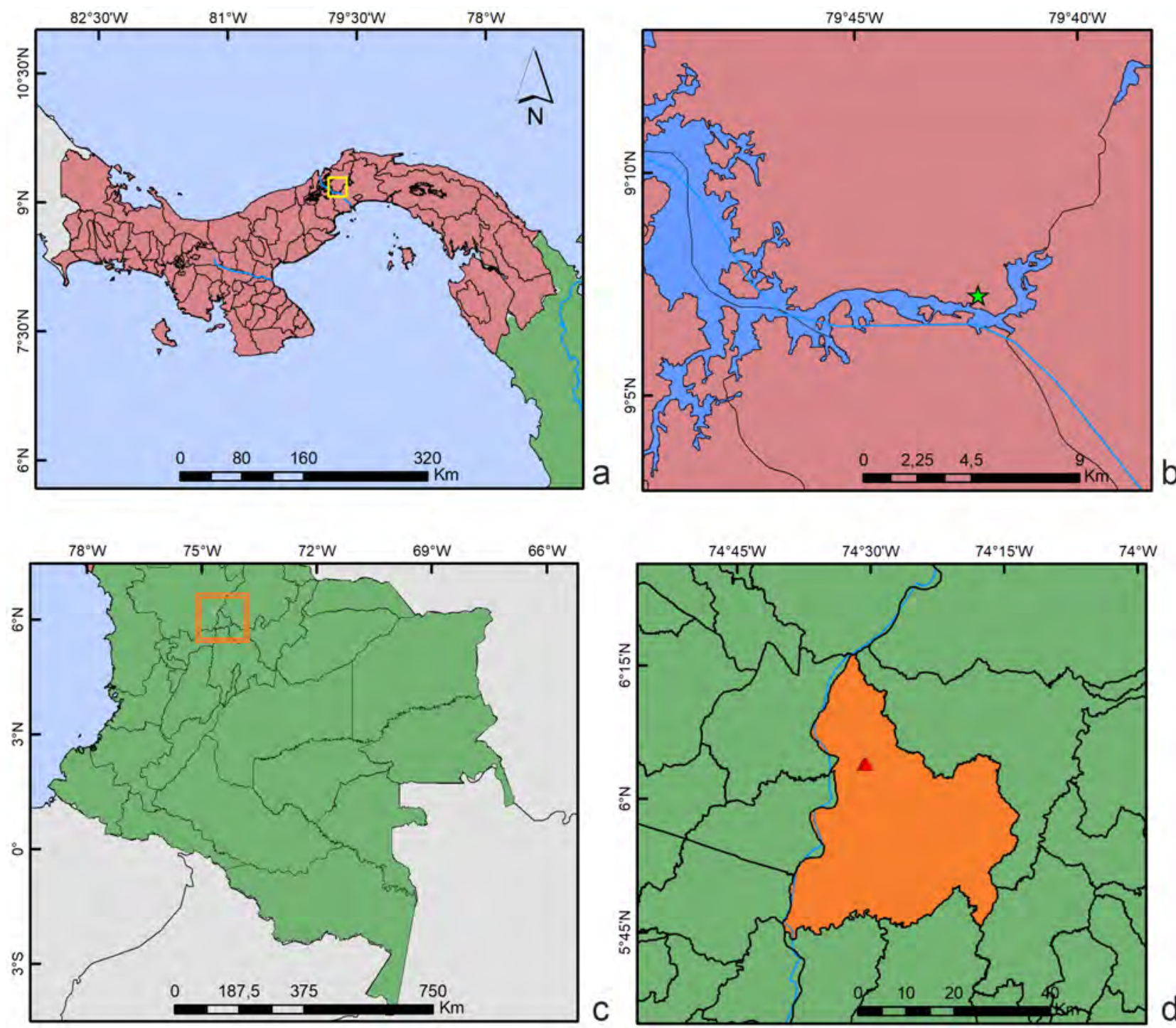

FIGURE 48. Distribution of new records of Microvelia fantastika Padilla-Gil, 2019. Panamá (a-b) in pink and Colombia (c-d) in green. Highlights indicate areas enlarged in the next maps. Green star (b) and red triangle (d) indicate the locations where specimens were sampled. 
Remarks. At first, we identified the specimens above as representatives of a new species and prepared a description. However, when we studied the recently published book by Padilla-Gil (2019a), it was possible to identify our specimens as Mi. fantastika. It is noteworthy that the pronotum of this species was misinterpreted by the author as almost completely covering the dorsum of the thorax, except for the lateral metathoracic triangles, when it in fact it covers the mesonotum, but leaves the metanotum exposed (Figs 37, 41, 43). The metanotum was mistakenly interpreted as a posterior lobe of the pronotum by Padilla-Gil (2019a). This species was previously known from Cesar and Nariño departments, respectively in northern and southwestern Colombia. The new records above are the first from Boyacá Department, in the central portion of the same country, and from Panama. The specimens from Boyacá were collected in the Palagua swampy complex (ciénaga), both in the swamp itself (Fig. 63) and in two adjacent lakes (jagüeyes) (Fig. 64). The Palagua swamp is a lentic water system directly connected to the Magdalena River, whereas the lakes are artificial structures built for water storage. The samples were associated with aquatic vegetation in the lakes and with the dominant hydrophytes (Eichhornia crassipes (Mart.) Solms and Pistia stratiotes L.) in the swamp.

\section{Microvelia mimula White, 1879}

(Figs 50, 53)

New records. PANAMA • 1 macropterous male; Colón, Gamboa, artificial pool; $9.12086^{\circ}$ N, $-79.70374^{\circ}$ W; 9 May 2015; A.J.J. Crumière leg.; CEIOC 79924.

Remarks. This species ranges from Cuba to Trinidad \& Tobago in the Caribbean Sea, and from Costa Rica to Uruguay (Pérez-Gelabert \& Floriano 2016). Drake \& Hussey (1955) listed Mi. mimula from Panama, without any details, and we confirm here the occurrence of the species in the country.
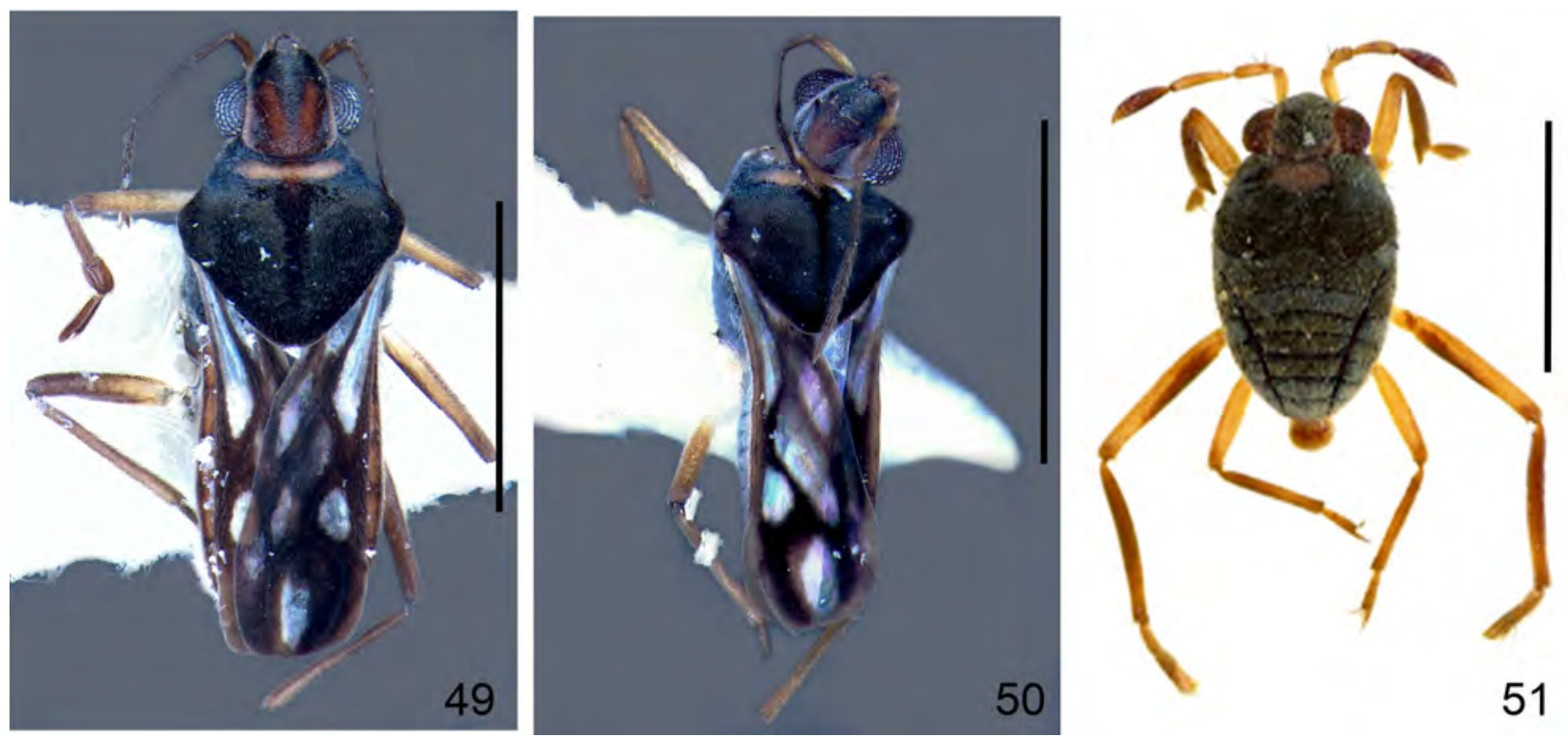

FIGURES 49-51. Habitus, dorsal view. 49, Microvelia albonotata Champion, 1898. 50, Mi. mimula White, 1879. 51, Euvelia advena Drake, 1957. Scale bars: $1.0 \mathrm{~mm}$.

\section{Euvelia advena Drake, 1957}

(Figs 51-52)

New records. COLOMBIA 1 apterous female; Amazonas, Leticia, Lago Madrevieja, Quebrada Mata Mata, 85m, 348’48.9” S 70¹5’6.8” W; Oct 2008; A. Solano leg.; COMAC. • 1 apterous male, 1 apterous female; Amazonas, Leticia, Quebrada Mata Mata, desembocadura Río Amazonas; Oct 2017; A. Solano leg.; UPTC: 17487. • 1 apterous male, 1 apterous female; Caquetá, Solano, Caño Orotuya, 0¹8’10.7” S 7442’48” W; 9 Oct 2010, C. Serrato leg.; COMAC. 
Remarks. This species was described from Bolivia (Drake 1957) and later recorded from Brazil and Peru (Aristizábal-García 2017). We present here its first record from Colombia.
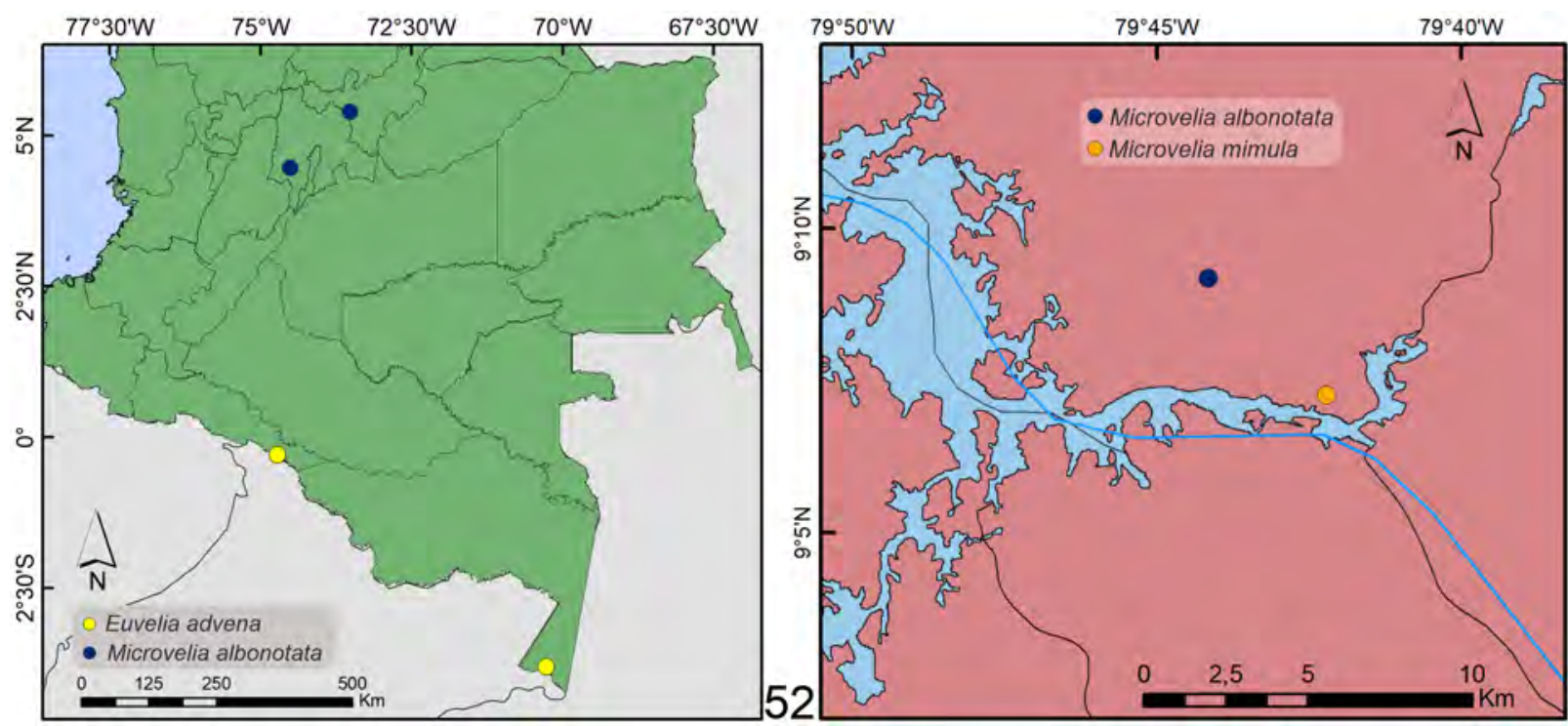

FIGURES 52-53. Distribution of new records. 52, Colombia; Euvelia advena Drake, 1957 in yellow circle; Microvelia albonotata Champion, 1898 in blue circle. 53, Panama; Mi. albonotata in blue circle; Mi. mimula White, 1879 in orange circle.

\section{Gerridae: Trepobatinae}

\section{Metrobates laudatus Drake \& Harris, 1937}

(Figs 54, 61)

New records. PANAMA • 1 apterous male, 2 apterous females; Colón, PR, Folijes River; $9.15244^{\circ}$ N, $-79.73739^{\circ}$ W / $9.15282^{\circ}$ N, -79.73351 W; 7 May 2015; A.J.J. Crumière leg.; CEIOC 79957.

Remarks. Metrobates laudatus has been recorded from Puerto Rico (Drake \& Harris 1937), Costa Rica (Polhemus \& Polhemus 2002, Pacheco-Chaves et al. 2018) and Panama (Polhemus \& Polhemus 2002). The previous report from Panama was provided without further details, and the occurrence of this species in the country is herein confirmed.

\section{Telmatometra ujhelyii Esaki, 1926}

(Figs 55-56, 61)

New records. PANAMA • 1 macropterous male, 2 apterous females Colón, PR, Folijes River; 9.15244 N, 79.73739 W / 9.15282 N, -79.73351º W; 7 May 2015; A.J.J. Crumière leg.; CEIOC 81258, CEIOC 81259.

Remarks. This species has been recorded from Puerto Rico, and from Mexico to Ecuador, with several gaps in Central America (Pacheco-Chaves et al. 2018). There is only one previous record from Panama, in the Canal Zone (Drake \& Harris 1937), and we report here its occurrence in Colón Province for the first time.

\section{Gerridae: Cylindrostethinae}

\section{Potamobates anchicaya Polhemus \& Polhemus, 1995}

(Figs 57, 62)

New records. PANAMA $\bullet 4$ apterous males, 3 apterous females; Colón, Pipeline Road, Seda River; 9.15329 N, -79.73663 W; 6 May 2015; A.J.J. Crumière leg.; CEIOC 81265 • 2 macropterous males; Colón, PR, Folijes River; 


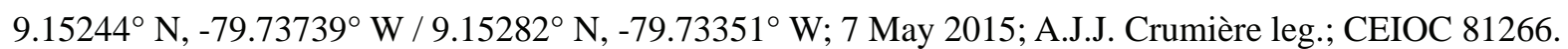

Remarks. Potamobates anchicaya is distributed from Panama to northern Ecuador (Buzzetti 2006). It is apparently quite common near our sampling stations in Colón and was also collected in Panama and Kuna Yala provinces (Polhemus \& Polhemus 1995).

\section{Gerridae: Charmatometrinae}

\section{Brachymetra albinervus (Amyot \& Serville, 1843)}

(Figs 58, 62)

New records. PANAMA - 3 macropterous males, 7 macropterous females; Colón, Pipeline Road, Seda River; 9.15329 ${ }^{\circ}$ N, -79.73663 W; 6 May 2015; A.J.J. Crumière leg.; CEIOC 81263 • 2 macropterous males; Colón, Pipeline Road, Seda River; 9.15329 N, -79.73663 W; 7 May 2015; A.J.J. Crumière leg.; CEIOC 81264.
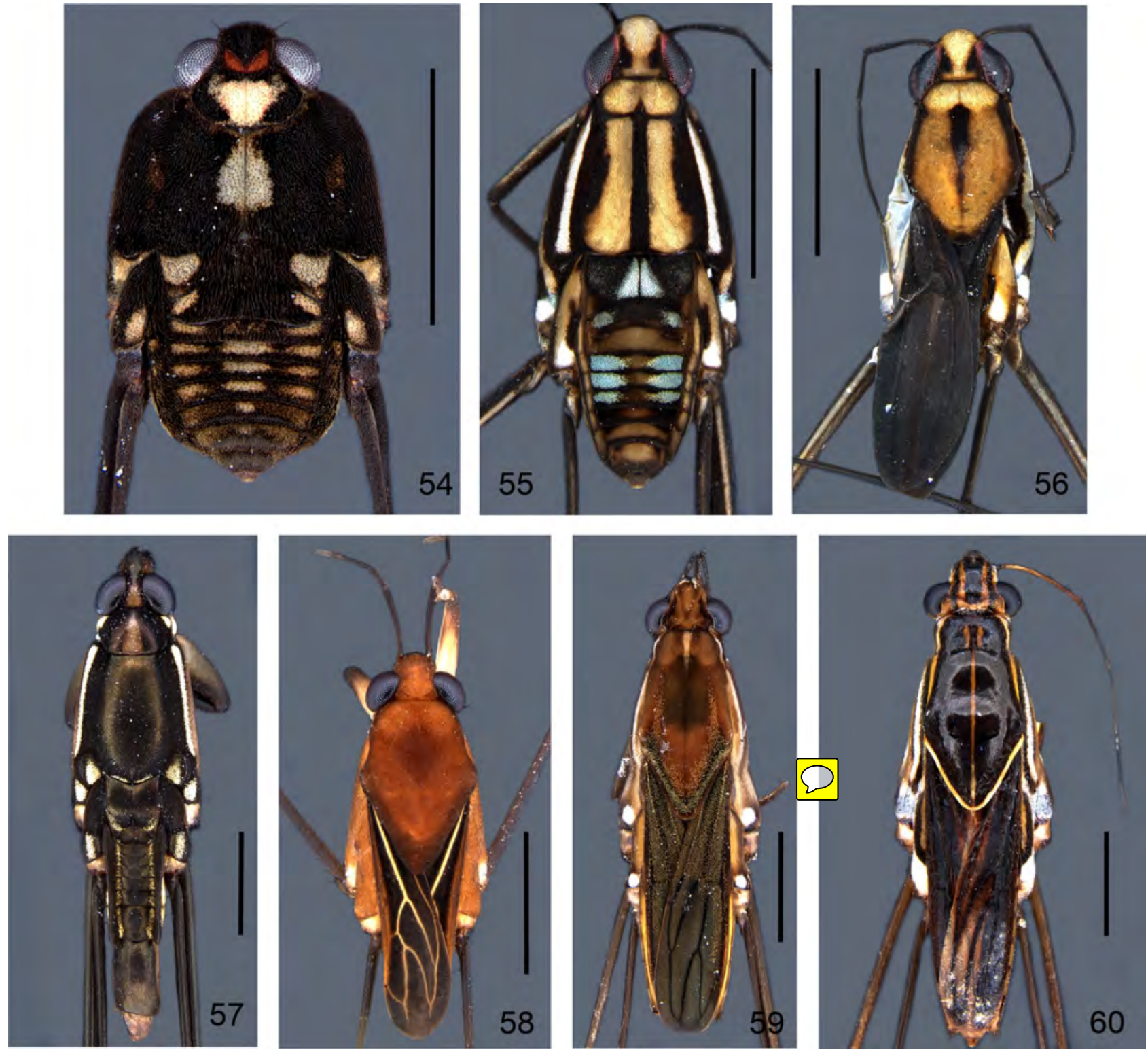

FIGURES 54-60. Habitus, dorsal view. 54, Metrobates laudatus Drake \& Harris, 1937. 55-56, Telmatometra ujhelyii Esaki, 1926. 55, Apterous. 56, Macropterous. 57, Potamobates anchicaya Polhemus \& Polhemus, 1995. 58, Brachymetra albinervus (Amyot \& Serville, 1843). 59, Limnogonus hyalinus (Fabricius, 1803). 60, Tachygerris opacus (Champion, 1898). Scale bars: $2.0 \mathrm{~mm}$. 
Remarks. This species is by far the most widely distributed of the genus, ranging from Guatemala (Drake \& Harris 1942) to Paraguay (Drake \& Harris 1930). It has three previous records from Panama (Allee \& Torvik 1927; Shaw 1933) and Chiriquí (Champion 1898) provinces, and the occurrence in Colón Province is herein reported for the first time.

\section{Gerridae: Gerrinae}

\section{Limnogonus hyalinus (Fabricius, 1803)}

(Figs 60, 62)

New records. PANAMA 3 apterous males, 2 macropterous males, 5 macropterous females; Colón, Gamboa, artificial pool; 9.12086 N, -79.70374 W; 9 May 2015; A.J.J. Crumière leg.; CEIOC 79958.

Remarks. Limnogonus hyalinus has been recorded from Costa Rica and Trinidad \& Tobago southward to Bolivia (Moreira et al. 2016; Pacheco-Chaves et al. 2018), with a few gaps. It is herein recorded for the first time from Panama.

\section{Tachygerris opacus (Champion, 1898)}

(Figs 59, 62)

New records. PANAMA - 5 macropterous male, 2 macropterous females; Colón, Pipeline Road, Seda River; 9.15329 ${ }^{\circ}$ N, - $79.73663^{\circ}$ W; 6 May 2015; A.J.J. Crumière leg.; CEIOC 81260 • 2 macropterous females; Colón,

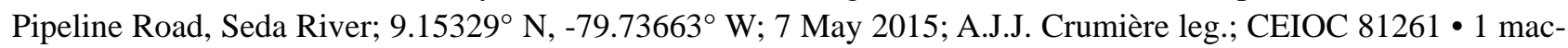
ropterous female; Panama, Plantation Road, dry creek, puddle; 9.08556 ${ }^{\circ}$ N, - $79.65841^{\circ}$ W; 17 May 2015; A.J.J. Crumière leg.; CEIOC 79956.

Remarks. Tachygerris opacus is found mainly west of the Andes, from Belize to Ecuador (Pacheco-Chaves et al. 2018), with more scarce reports from the Amazon (e.g., Kuitert 1942; Nieser 1970; Morales \& Molano 2009). It has been recorded a few times from Panama, including the provinces of Chiriquí (Champion 1898) and Panama (Champion 1898; Torre-Bueno 1926; Kuitert 1942; Calabrese \& Tallerico 1987; Damgaard et al. 2014). We report here the occurrence of the species in Colón Province for the first time.
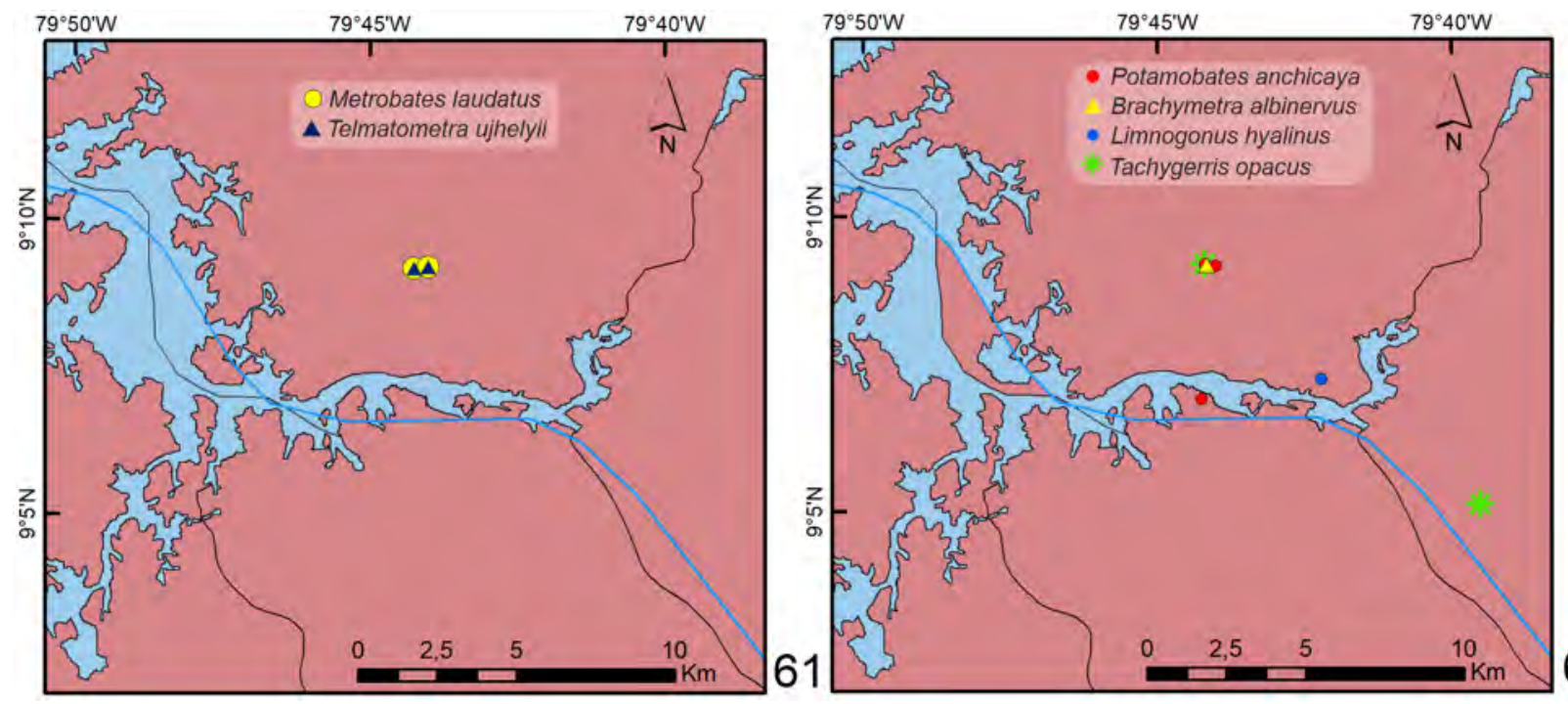

FIGURES 61-62. Distribution of new records from Panamá. 61, Metrobates laudatus Drake \& Harris, 1937 in yellow circle; Telmatometra ujhelyii Esaki, 1926 in blue triangle. 62, Potamobates anchicaya Polhemus \& Polhemus, 1995 in red circle; Brachymetra albinervus (Amyot \& Serville, 1843) in yellow triangle; Limnogonus hyalinus (Fabricius, 1803) in blue circle; Tachygerris opacus (Champion, 1898) in green asterisk. 


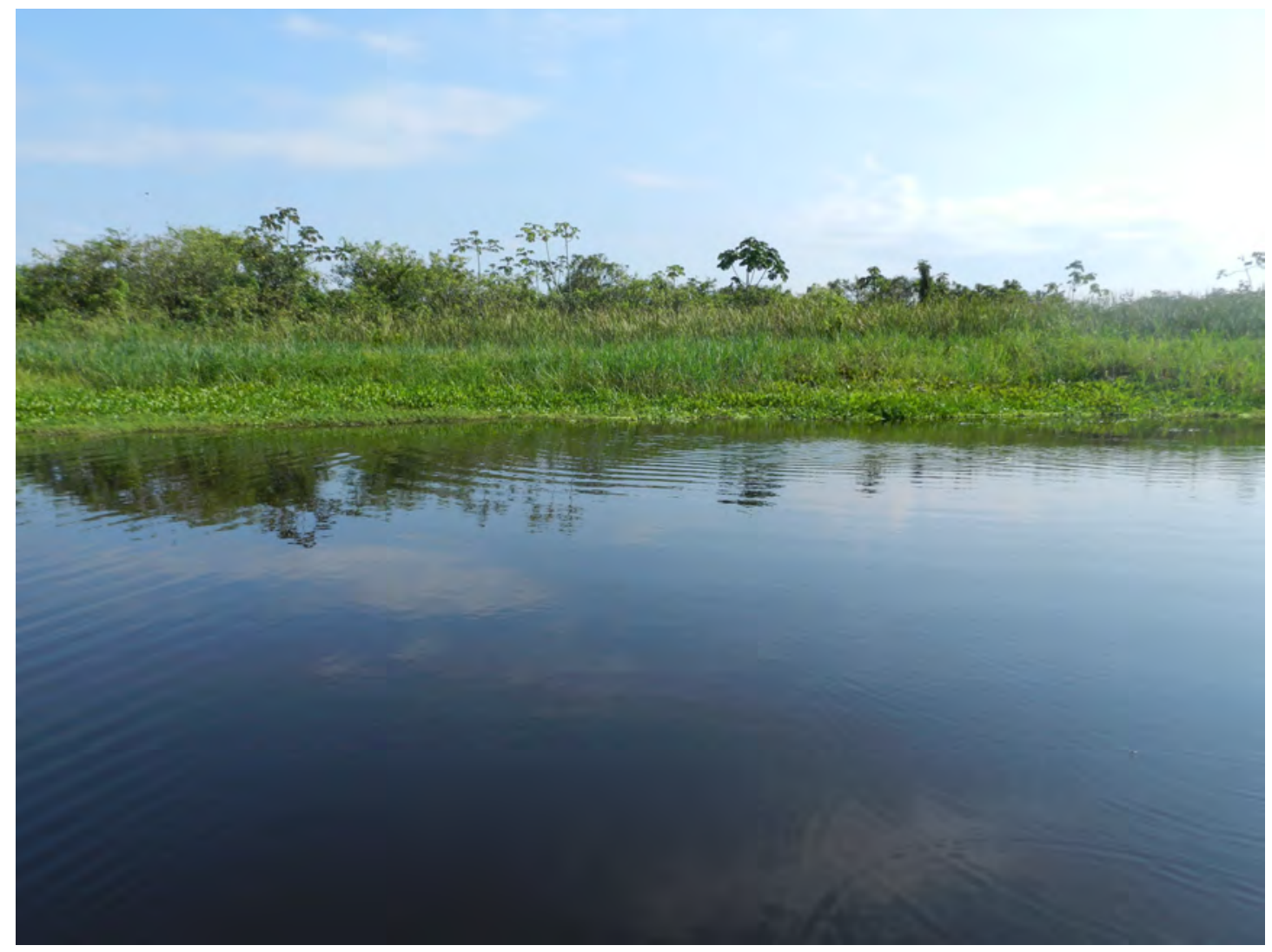

FIGURE 63. Palagua swamp (Ciénaga de Palagua), Vereda Muelle Velásquez, Puerto Boyacá, Boyacá, Colombia, where Microvelia fantastika Padilla-Gil, 2019 was collected.

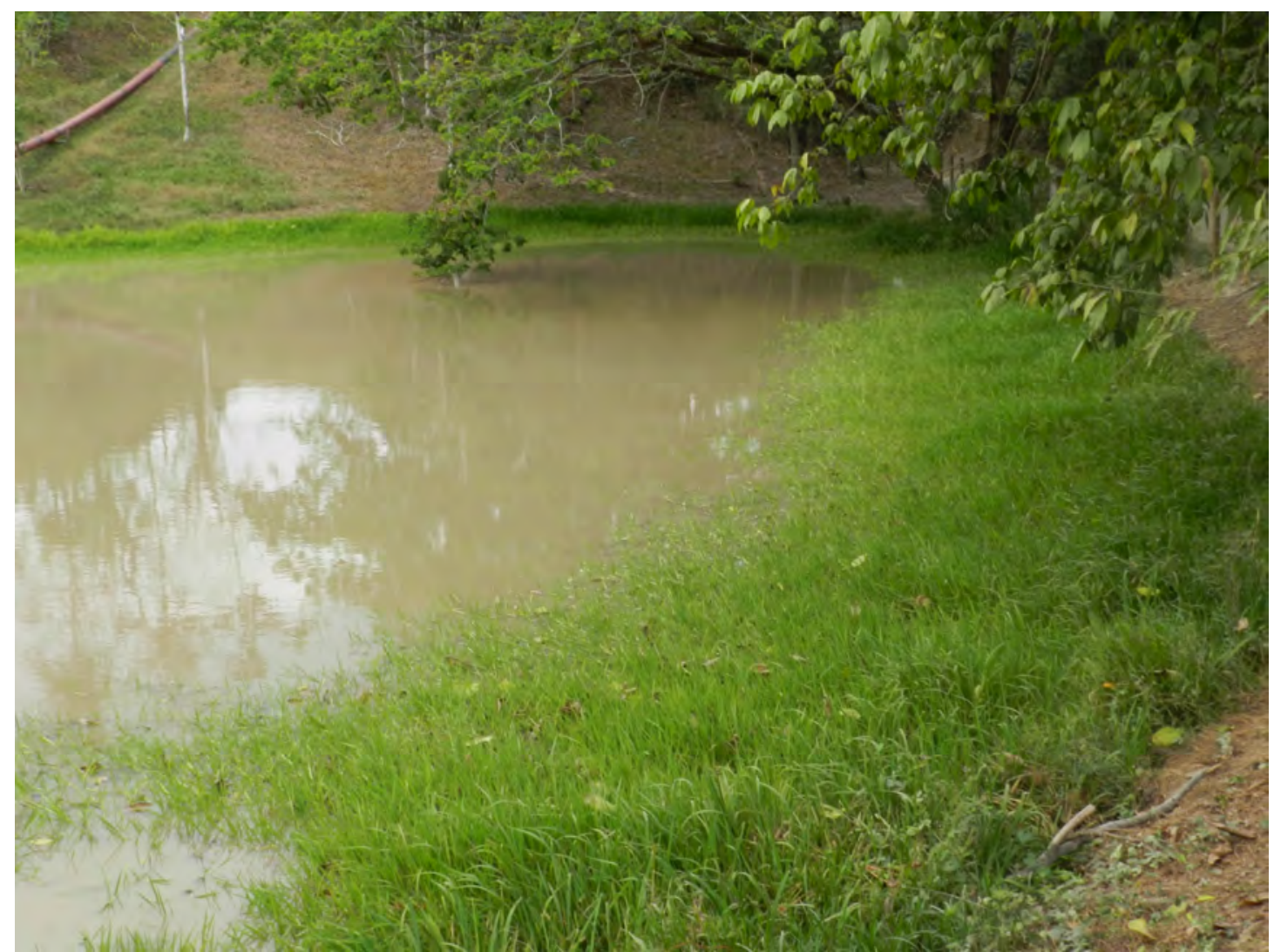

FIGURE 64. Artificial lake (jagüey), Vereda Muelle Velásquez, Puerto Boyacá, Boyacá, Colombia, where Microvelia fantastika Padilla-Gil, 2019 was collected. 


\section{Acknowledgements}

The manuscript of this paper benefited from the useful comments of Drs. Cristiano F. Schwertner, Shruti Paripatyadar and Stephen W. Chordas III. This work was conducted with permits from the Ministerio de Ambiente, República de Panamá (research permit SE/A-43-15; export permit SEX/A-57-15) and partially supported by the European Research Council ERC-CoG \# 616346 and the Agence National de la Recherche, France (ANR Convergenomix), to AK. JMSR benefited from a postdoctoral fellowship (\#202.317/2018) provided by the State of Rio de Janeiro Research Foundation (FAPERJ). AJJC thanks Rachelle M. M. Adams and Jonathan Z. Shik for scientific mentoring during fieldwork and the Smithsonian Tropical Research Institute, Panama, for the administrative and logistic support. AJJC benefited from the Libbie H. Hyman Memorial Scholarship 2015 provided by the Society for Integrative \& Comparative Biology. IM and SPMF thank the Dirección de Investigaciones from the Universidad Pedagógica y Tecnológica de Colombia for the financial support with the project "Diversidad taxonómica y genética de chinches acuáticas y semiacuáticas (Insecta: Hemiptera), asociadas al complejo cenagoso de Palagua, Puerto Boyacá, Colombia: implicaciones para su conservación”, SGI 2647. FFFM benefited from grants provided by FAPERJ (\#210.508/2016, \#202.551/2017, \#203.207/2017) and the National Council for Scientific and Technological Development (CNPq; \#301942/2019-6).

\section{References}

Allee, W.C. \& Torvik, M. (1927) Factors Affecting Animal Distribution in a Small Stream of the Panama Rain-Forest in the Dry Season. Journal of Ecology, 15, 66-71. https://doi.org/10.2307/2256064

Aristizábal-García, H. (2017) Hemípteros Acuáticos y Semiacuáticos del Neotrópico. Academia Colombiana de Ciencias Exactas Físicas y Naturales, Bogotá, $984+601$ pp.

Bacon, J.A. (1956) A Taxonomic Study of the Genus Rhagovelia (Hemiptera, Veliidae) of the Western Hemisphere. University of Kansas Science Bulletin, 38, 695-913.

Buzzetti, F.M. (2006) The genus Potamobates Champion in Ecuador, with description of P. shuar n. sp. (Hemiptera: Gerridae). Zootaxa, 1306 (1), 51-56. https://doi.org/10.11646/zootaxa.1306.1.4

Calabrese, D.M. \& Tallerico, P. (1987) Chromosome study of two Neotropical species of Gerridae (Hemiptera: Heteroptera). Journal of the New York Entomological Society, 95, 338-340.

Castro-Vargas, M.I., Morales, I. \& Molano-Rendon, F. (2018) A new species of Metrobates Uhler, 1871 (Hemiptera: Heteroptera: Gerridae) from Colombia. Zootaxa, 4379 (4), 567-575. https://doi.org/10.11646/zootaxa.4379.4.8

Champion, G.C. (1898) Insecta. Rhynchota. Hemiptera-Heteroptera. In: Godman, F.D. \& Salvin, O. (Eds.), Biologia CentraliAmericana. Vol. II. Taylor \& Francis, London, pp. i-xvi + 1-416 pp., 22 pls.

Cobos-Vallejo, J.R., Orozco-Cardona, A.F. \& Gómez-Marín, G.D. (2007) Caracterización de la flora y heterópteros acuáticos y semiacuáticos en ecosistemas lóticos de la Reserva Natural La Montaña del Ocaso. Centro de Estudios e Investigaciones en Biodiversidad y Biotecnología, Armenia, $52 \mathrm{pp}$.

Damgaard, J., Moreira, F.F.F., Hayashi, M., Weir, T.A. \& Zettel, H. (2012) Molecular phylogeny of the pond treaders (Insecta: Hemiptera: Heteroptera: Mesoveliidae), discussion of the fossil record and a checklist of species assigned to the family. Insect Systematics \& Evolution, 43, 175-212. https://doi.org/10.1163/1876312X04302004

Damgaard, J., Moreira, F.F.F., Weir, T.A. \& Zettel, H. (2014) Molecular phylogeny of the pond skaters (Gerrinae), discussion of the fossil record and a checklist of species assigned to the subfamily (Hemiptera: Heteroptera: Gerridae). Insect Systematics \& Evolution, 45, 251-281. https://doi.org/10.1163/1876312X-44042105

Drake, C.J. (1948) Concerning some Tropical Rhagovelia (Hemiptera: Veliidae). Boletín de Entomología Venezolana, 7, 141144.

Drake, C.J. (1957) New Neotropical water-striders (Hemiptera). Proceedings of the Entomological Society of Washington, 70, $111-117$.

Drake, C.J. \& Chapman, H.C. (1958) New Neotropical Hebridae, including a catalogue of the American species (Hemiptera). Journal of the Washington Academy of Sciences, 48, 317-326.

Drake, C.J. \& Harris, H.M. (1930) Notes on some South American Gerridae (Hemiptera). Annals of the Carnegie Museum, 19, 235-239.

Drake, C.J. \& Harris, H.M. (1937) Notes on some American Halobatinae (Gerridae, Hemiptera). Revista de Entomologia, 7, 357-362. 
Drake, C.J. \& Harris, H.M. (1942) A new Brachymetra from Venezuela (Hemiptera-Gerridae). Boletin de Entomologia Venezolana, 1, 95-97.

Drake, C.J. \& Hussey, R.F. (1951) Concerning some American Microvelia (Hemiptera: Veliidae). Florida Entomologist, 34, 137-145. https://doi.org/10.2307/3492444

Drake, C.J. \& Hussey, R.F. (1955) Concerning the genus Microvelia Westwood, with descriptions of two new species and a check-list of the American forms (Hemiptera: Veliidae). Florida Entomologist, 38, 95-115. https://doi.org/10.2307/3492200

Floriano, C.F.B., Molano-Rendón, F., Morales, I., Moreira, F.F.F. \& Bispo, P.C. (2019) Revision of the genus Platygerris White, 1833 (Hemiptera: Heteroptera: Gerridae), with descriptions of two new species from Colombia. Insect Systematics \& Evolution, 51 (4), 672-695. https://doi.org/10.1163/1876312X-00002306

Floriano, C.F.B., Moreira, F.F.F. \& Bispo, P.D.C. (2017) South American species of Stridulivelia (Hemiptera: Heteroptera: Veliidae): identification key, diagnoses, illustrations, and updated distribution. Proceedings of the Entomological Society of Washington, 119, 24-46. https://doi.org/10.4289/0013-8797.119.1.24

Floriano, C.F.B., Moreira, F.F.F., Bispo, P.C., Morales, I. \& Molano-Rendón, F.M. (2016) A new species of Mesovelia (Heteroptera: Gerromorpha: Mesoveliidae) from South America, with identification key and notes on Colombian species. Zootaxa, 4175 (4), 345-352. https://doi.org/10.11646/zootaxa.4175.4.4

Gould, G.E. (1931) The Rhagovelia of the Western Hemisphere, with notes on World distribution (Hemiptera, Veliidae). University of Kansas Science Bulletin, 20, 5-61. https://doi.org/10.5962/bhl.part.19193

Kuitert, L.C. (1942) Gerrinae in University of Kansas Collections. University of Kansas Science Bulletin, 28, 113-143.

Martínez, D.C., Galindo-Malagón, X.A., Molano, F. \& Moreira, F.F.F. (2019) Descriptions, records, and key to the Hydrometra Latreille, 1796 (Hemiptera: Heteroptera: Hydrometridae) from Colombia. Zootaxa, 4577 (1), 51-72. https://doi.org/10.11646/zootaxa.4577.1.3

Mazzucconi, S.A., López-Ruf, M.L. \& Bachmann, A.O. (2009) Hemiptera-Heteroptera: Gerromorpha y Nepomorpha. In: Domínguez, E. \& Fernández, H.R. (Eds.), Macroinvertebrados Bentônicos Sudamericanos. Sistemática y Biologia. Fundación Miguel Lillo, Tucumán, pp. 167-231.

Molano, F., Mondragón-F., S.P. \& Morales, I. (2017a) A new species of Rheumatobates Bergroth (Hemiptera: Heteroptera: Gerridae) from mangroves of the Colombian Caribbean region, new records, and a key to species recorded from the country. Zootaxa, 4277 (2), 252-260. https://doi.org/10.11646/zootaxa.4277.2.5

Molano, F., Mondragón-F., P. \& Morales I. (2017b) Nueva especie y nuevos registros de Telmatometra (Hemiptera: Gerridae) en Colombia. Ciencia en Desarrollo, 8, 93-98. https://doi.org/10.19053/01217488.v8.n1.2017.4799

Molano, F., Mondragón, S.P. \& Morales, I. (2018a) Nuevas especies de chinches patinadoras (Hemiptera: Heteroptera: Gerridae) de Colombia. Acta Biológica Colombiana, 23, 179-188. https://doi.org/10.15446/abc. v23n2.66855

Molano, F., Morales, I. \& Moreira, F.F.F. (2018b) Two new species and key to the salina group of the genus Rhagovelia Mayr, 1865 (Hemiptera: Heteroptera: Veliidae) from Colombia. Zootaxa, 4457 (2), 305-314. https://doi.org/10.11646/zootaxa.4457.2.7

Molano, F. \& Morales, I. (2017) Chinches patinadoras marinas (Hemiptera: Heteroptera: Gerromorpha): diversidad de los hábitats oceánicos del neotrópico. Biota Colombiana, 18, 172-191. https://doi.org/10.21068/c2017.v18n01a10

Mondragón-F., S.P., Molano, F. \& Morales, I. (2017) Cinco nuevas especies de Tachygerris (Hemiptera: Gerridae: Gerrinae) y nuevos registros para Colombia. Caldasia, 39, 204-220. https://doi.org/10.15446/caldasia.v39n2.60603

Morales, I. \& Molano, F. (2009) Revisión de los géneros Eurygerris y Tachygerris (Hemiptera: Tachygerrini) para la region neotropical. Revista Mexicana de Biodiversidad, 80, 396-410. https://doi.org/10.22201/ib.20078706e.2009.002.608

Morales, I., Molano, F. \& Moreira, F.F.F. (2020) Veliidae (Insecta: Heteroptera: Gerromorpha) from Colombia: description of a new species and of the male of Euvelia meta Molano, Moreira \& Morales, 2016. Revista Brasileira de Entomologia, 64, $1-6$. https://doi.org/10.1590/1806-9665-rbent-e2019-91

Moreira, F.F.F. (2015) The semiaquatic gerromorphans. In: Panizzi, A.R. \& Grazia, J. (Eds.), True Bugs (Heteroptera) of the Neotropics. Springer, Dordrecht, pp. 113-156. https://doi.org/10.1007/978-94-017-9861-7_6

Moreira, F.F.F., Rodrigues, H.D.D., Barbosa, J.F., Reduciendo-Klementová, B. \& Svitok, M. (2016) New records of Gerromorpha and Nepomorpha (Insecta: Hemiptera: Heteroptera) from South America. Biodiversity Data Journal, 4, e7975. 
https://doi.org/10.3897/BDJ.4.e7975

Moreno, C., Molina, W., Barbosa, J.F. \& Moreira, F.F.F. (2018) Aquatic and semiaquatic bugs (Insecta, Hemiptera, Heteroptera) from Toluviejo Municipality, Sucre Department, Caribbean region of Colombia. Check List, 14, 985-1002. https://doi.org/10.15560/14.6.985

Nieser, N. (1970) Gerridae of Suriname and the Amazon with additional records of other Neotropical species. Studies on the Fauna of Suriname and other Guyanas, 12, 94-138.

Nieser, N. \& Melo, A.L. (1997) Os Heterópteros Aquáticos de Minas Gerais - Guia Introdutório com Chave de Identificação para as Espécies de Nepomorpha e Gerromorpha. Editora UFMG, Belo Horizonte, 177 pp.

Pacheco-Chaves, B., Cordeiro, I.R.S., Moreira, F.F.F. \& Springer, M. (2018) The water striders (Hemiptera: Heteroptera: Gerridae) of Costa Rica: new species, checklist, and new records. Zootaxa, 4471 (3), 493-522. https://doi.org/10.11646/zootaxa.4471.3.4

Pacheco-Chaves, B., Moreira, F.F.F. \& Springer, M. (2014) New records of Gerromorpha (Insecta: Hemiptera: Heteroptera) from Costa Rica. CheckList, 10, 180-186. https://doi.org/10.15560/10.1.180

Padilla-Gil, D.N. (2011) Ten new species of Rhagovelia in the R. angustipes complex from Colombia (Heteroptera: Veliidae). Aquatic Insects, 33, 203-231. https://doi.org/10.1080/01650424.2011.597404

Padilla-Gil, D.N. (2017) Composición y estructura de heterópteros (Hemiptera) en ecosistemas lóticos costeros del Pacífico colombiano. Actualidades Biológicas, 39, 51-57. https://doi.org/10.17533/udea.acbi.v39n107a06

Padilla-Gil, D.N. (2019a) Nuevas especies de Rhagovelia, Microvelia, Buenoa Registros nuevos de otros heterópteros de Colombia (Gerromorpha, Nepomorpha, Leptopodomorpha). Editorial Académica Española, Beau Bassin, 242 pp.

Padilla-Gil, D.N. (2019b) Diversidad del género Rhagovelia (Hemiptera: Heteroptera: Veliidae) del piedemonte AndinoAmazónico (Putumayo, Colombia). Acta Biológica Colombiana, 24, 174-179. https://doi.org/10.15446/abc.v24n1.66352

Parra-Trujillo, Y.T., Padilla-Gil, D.N. \& Flórez, G.R. (2014) Diversidad y distribución de Rhagovelia (Hemiptera, Veliidae) del departamento del Tolima. Revista de la Asociación Colombiana de Ciencias Biológicas, 26, 79-85.

Pérez-Gelabert, D.E. \& Floriano, C.F.B. (2016) New records of the water strider Platyvelia brachialis (Stål 1860) (Hemiptera: Heteroptera: Veliidae) from the Dominican Republic and Haiti, with a checklist of the West Indian Veliidae. Proceedings of the Entomological Society of Washington, 118, 471-476. https://doi.org/10.4289/0013-8797.118.3.471

Polhemus, D.A. (1997) Systematics of the Genus Rhagovelia Mayr (Heteroptera: Veliidae) in the Western Hemisphere (Exclusive of the angustipes Complex). Entomological Society of America, Langham, ii + $386 \mathrm{pp}$.

Polhemus, D.A., Molano, F., Morales, I., Moreira, F.F.F. \& Floriano, C.F.B. (2019) Altavelia, a new genus of Neotropical Veliinae (Heteroptera: Gerromorpha: Veliidae), with a key to species and descriptions of four new species from Colombia. Zootaxa, 4585 (2), 295-314. https://doi.org/10.11646/zootaxa.4585.2.4

Polhemus, J.T. \& Polhemus, D.A. (1995) A phylogenetic review of the Potamobates fauna of Colombia (Heteroptera: Gerridae), with descriptions of three new species. Proceedings of the Entomological Society of Washington, 97, 350-372.

Polhemus, J.T. \& Polhemus, D.A. (2002) The Trepobatinae (Gerridae) of New Guinea and surrounding regions, with a review of the world fauna. Part 6. Phylogeny, biogeography, world checklist, bibliography and final taxonomic addenda. Insect Systematics and Evolution, 33, 253-290. https://doi.org/10.1163/187631202X00154

Polhemus, J.T. \& Polhemus, D.A. (2007) Global trends in the description of aquatic and semiaquatic Heteroptera species, 1758-2004. Tijdschrift voor Entomologie, 150, 271-288. https://doi.org/10.1163/22119434-900000230

Polhemus, J.T. \& Polhemus, D.A. (2008) Global diversity of true bugs (Heteroptera; Insecta) in freshwater. Hydrobiologia, 595, 379-391. https://doi.org/10.1007/s10750-007-9033-1

Shaw, J.G. (1933) A study of the Genus Brachymetra (Hemiptera-Gerridae). University of Kansas Science Bulletin, 21, 221233.

Smith, C.L. (1988) Family Veliidae Amyot and Serville, 1843. The Small Water Striders. In: Henry, T.J. \& Froeschner, R.C. (Eds.), Catalog of the Heteroptera, or True Bugs, of Canada and the Continental United States. E. J. Brill, Leiden, pp. 734-742. https://doi.org/10.1201/9781351070447-45

Torre-Bueno, J.R. (1926) On some Heteroptera from the Canal Zone, collected by Dr. J.G. Sanders. Bulletin of the Brooklyn Entomological Society, 21, 108.

Tuñon, A., Cornejo, A., Nieto, C., Padilla-Gil, D.N. \& Pacheco-Chaves, B. (2015) Heterópteros (Insecta: Hemiptera) dulceacuícolas de Panamá: listado de especies, distribución de géneros y comparación con la riqueza taxonómica de Centroamérica. Puente Biológico, 7, 131-173. 